\title{
Astrobiology
}

Astrobiology Manuscript Central: http://mc.manuscriptcentral.com/astrobiology

\section{Laboratory analysis of returned samples from the AMADEE- 18 Mars analog mission}

\begin{tabular}{|c|c|}
\hline Journal: & Astrobiology \\
\hline Manuscript ID & AST-2019-2038.R3 \\
\hline Manuscript Type: & Special Collection: Amadee-18 \\
\hline $\begin{array}{r}\text { Date Submitted by the } \\
\text { Author: }\end{array}$ & 29-Nov-2019 \\
\hline Complete List of Authors: & $\begin{array}{l}\text { Lalla, Emmanuel; York University, Center of Research in Earth and Space } \\
\text { Science; Austrian Space Forum, } \\
\text { Cote, Kristen; York University, Center of Research in Earth and Space } \\
\text { Science } \\
\text { Hickson, Dylan; York University, Center of Research in Earth and Space } \\
\text { Science } \\
\text { Garnitschnig, Stefanie; Austrian Space Forum, Innsbruck office; } \\
\text { Universitat Innsbruck, Institute of Ecology } \\
\text { Konstantinidis, Menelaos; York University, Center of Research in Earth } \\
\text { and Space Science } \\
\text { Such, Pamela; York University, Center of Research in Earth and Space } \\
\text { Science } \\
\text { Czakler, Christine; Austrian Space Forum, } \\
\text { Schroeder, Christian; University of Stirling, Biological and Environmental } \\
\text { Sciences } \\
\text { Frigeri, Alessadro; Istituto nazionale di astrofisica, Institute for Space } \\
\text { Astrophysics and Planetology IAPS } \\
\text { Ercoli, Maurizio; Universita degli Studi di Perugia, Dipartimento di Fisica } \\
\text { e Geologia } \\
\text { Losiak, Anna; Austrian Space Forum; Polish Academy of Sciences, } \\
\text { Institute of Geological Science } \\
\text { Gruber, Sophie; Austrian Space Forum, AMADEE Programme Office } \\
\text { Groemer, Gernot; Austrian Space Forum, Spacesuit Laboratory }\end{array}$ \\
\hline Keyword: & Simulation, Analog, Mars, Spectroscopy, Planetary Geology \\
\hline $\begin{array}{r}\text { Manuscript Keywords (Search } \\
\text { Terms): }\end{array}$ & $\begin{array}{l}\text { Planetary exploration, combined instrumentation methods, Astrobiology, } \\
\text { simulated space mission }\end{array}$ \\
\hline \multicolumn{2}{|c|}{ Final publication is available from Mary Ann Liebert, Inc., publishers https://doi.org/10.1089/ast.2019.2038 } \\
\hline
\end{tabular}

\section{SCHOLARONE ${ }^{\text {w }}$ \\ Manuscripts}


Laboratory analysis of returned samples from the AMADEE-18 Mars

\section{analog mission}

E. Lalla ${ }^{1,2,{ }^{*}, \text { K. Cote }}{ }^{1, \dagger}$, D. Hickson ${ }^{1}$, S. Garnitschnig ${ }^{2}$, M. Konstantinidis ${ }^{1}$, P. Such ${ }^{1}$, C. Czakler ${ }^{2}$, C. Schroder ${ }^{3}$, A. Frigeri ${ }^{5}$, M. Ercoli ${ }^{6}$, A. Losiak $^{6,7,2}$, S. Gruber ${ }^{2}$, and G. Groemer ${ }^{2}$

${ }^{1}$ Centre for Research in Earth and Space Science (CRESS), York University, Toronto, Ontario, M3J 1P3, Canada.

${ }^{2}$ Austrian Space Forum, Etrichgasse 18, Innsbruck, 6020, Austria.

${ }^{3}$ Biological and Environmental Sciences, Faculty of Natural Sciences, University of Stirling, Stirling FK9 4LA, Scotland, UK.

${ }^{4}$ National Institute of Astrophysics · Institute for Space Astrophysics and Planetology IAPS, Viale del Parco Mellini 84, 00136, Rome, Italy.

${ }^{5}$ Università degli Studi di Perugia · Dipartimento di Fisica e Geologia, Piazza dell'Università, 1 - 06121, Perugia, Italy

${ }^{6}$ Institute of Geological Sciences, Polish Academy of Sciences, Polandul. Podwale 75, 50-449 Wroctaw, Poland.

${ }^{7}$ WildFire LabHatherly Laboratories, University of Exeter, Prince of Wales Road, Exeter, EX4 $4 P S U K$

†Current address: Department of Physics, University of Toronto, Toronto, Ontario, M5S 1A7, Canada

Corresponding author: Dr. Emmanuel Alexis Lalla (elalla@yorku.ca, emmanuel.1alla@oewf.org) 


\section{Abstract}

Between 01-28. February 2018, the Austrian Space Forum, in cooperation with the Oman Astronomical Society and research teams from 25 nations conducted the AMADEE-18 mission, a human-robotic Mars expedition simulation in the Dhofar region in the Sultanate of Oman As a part of the AMADEE-18 simulated Mars human exploration mission, the Remote Science Support team performed analysis of the Dhofar area, (Oman) in order to characterize it as a potential Mars analog site. The main motivation of this research was to study and register selected samples collected by the analog astronauts during the AMADEE-18 mission with laboratory analytical methods and techniques comparable to the techniques that will be used on Mars in the future. The 25 samples representing unconsolidated sediments obtained during the simulated mission were studied by using optical microscopy, Raman spectroscopy, X-ray diffraction, laserinduced breakdown spectroscopy, and laser-induced fluorescence. The principal results showed the existence of minerals and the detection of alteration processes related to volcanism, hydrothermalism, and weathering. The analogy between the Dhofar region and the Eridana Basin region of Mars is clearly noticeable, particularly as an analog for secondary minerals formed in a hydrothermal seafloor volcanic-sedimentary environment. The synergy between the techniques used in the present work provides a solid basis for the geochemical analyses and organic detection in the context of future human-robotic Mars expeditions. AMADEE-18 has been a prime test bed for geoscientific workflows with astrobiological relevance and has provided valuable insights for future space missions.

Keywords: Planetary exploration, combined instrumentation methods, Astrobiology, simulated space mission. 


\section{Introduction}

AMADEE-18 was an integrated Mars analog mission conducted by the Austrian Space Forum in the Dhofar region in the Sultanate of Oman between $01-28^{\text {th }}$ February 2018. The activities were carried out in the proposed terrestrial Martian analog site and directed by a Mission Support Center in Innsbruck, Austria (Groemer et al., 2019). During the planning stage of the mission, a sequential method for the detection of biomarkers for future human and robotic Mars missions was developed. Garnitschnig (2018) proposed a framework for the detection of potential biomarkers and compiled a list of potential test sites for future missions (Groemer et al., 2019; Groemer, 2018a). These kinds of methods and frameworks pursue a double objective with strong implications in the search of life on Mars and optimization in the synergy of analytical techniques at different test sites for future Martian missions. The first objective was to evaluate the impact of carbon detection, water evidence, and characterize any biosignature. The second objective was the rational selection of technique to be used, which was based on the Martian mission such as Mars2020 and ExoMars suit equipment. Thus, the synergistic combination of analyses are of interest for target selection, deployment outcrop site and instrumentation capabilities for water and possible life detection (Garnitschnig, 2018; Gruber et al., 2019; Stromberg et al., 2019).

Several in-situ experiments were used during this study such as the FieldSpec and ScanMars systems, which utilize reflectance spectroscopy and ground-penetrating radar GPR (described in detail in this issue). Other lab-based techniques that we have used during our analysis are microimaging, Raman spectroscopy, X-ray diffraction (XRD), laser-induced breakdown spectroscopy (LIBS), and laser-induced fluorescence (LIF). The objective of these methods is to have a full biological and geological understanding of the surface. In this work, we present the results of the analysis done using lab-based techniques and illustrate how they can be used to qualitatively and quantitatively describe landscapes in situ, in addition to analyzing samples collected by humans during analogue and/or actual space missions. This may facilitate the inference of a surface suitability for subsequent analyses. For example, the lab-techniques can help in future selection of instrumentation and design of the workflow for a possible field-survey.

The main motivation of this research was to study selected samples collected by the analog astronauts during the AMADEE-18 mission with laboratory analytical methods and techniques proposed in the strategic framework developed by (Garnitschnig, 2018) for the AMADE-18 mission and comparable to the techniques that will be used on Mars in the future. The analyses were performed at the Planetary Exploration Instrumentation Laboratory at York University and the Royal Ontario Museum, both in Toronto, Canada. The results and measurements exemplify the capabilities of each technique, and the combined advantages. Furthermore, the results emphasize the selection applicability of portable twin systems-those that resemble real flight 
instruments used in past/present/future Martian missions, and also based in the same technologyfor future analog missions. Table 1 compares laboratory-based rover instrumentation from past, current and future missions. Finally, SEM, EDS and XRD as described above, can be used to validate field experiments such as LIBS, Raman Spectroscopy and LIF.

\section{Methods used in this study and their relevance to Mars studies}

Raman spectroscopy is a non-destructive spectroscopic technique that does not require sample preparation. The technique is well suited for in-situ analyses of rocks and minerals, and has been used for mineral identification and organic detection of the target sample (Edwards et al., 2013; Ferraris et al., 2012). Raman spectroscopy has been proposed as a method for geological identification for Mars-related materials, and it will be used during the future Martian missions: SuperCam and SHERLOC (NASA Mars 2020) or the ESA-RLS System (ExoMars) (Beegle et al., 2015; Rull et al., 2017; Wiens et al., 2016).

LIBS utilizes emissions from plasma created at the surface of a sample via high-power laser pulses to perform quantitative chemical analyses (Wiens et al., 2012).. One of the primary benefits of LIBS is that there is no required sample preparation prior to measurement and only optical access to the sample is required. This makes it a formidable candidate for stand-off chemometric analysis (Cremers and Radziemski, 2013; Konstantinidis et al., 2019). For these reasons LIBS was selected for flight on Curiosity in the ChemCam instrument (Anderson et al., 2015), and will fly on Mars 2020 (Wiens et al., 2016).

LIF provides a method for organic and mineral detection through excitation of molecules by the absorption of laser light followed by spontaneous emission of light (Storrie-Lombardi et al., 2009). Typically, LIF used to be understood as an undesired byproduct of a Raman measurement, but (Eshelman et al., 2018) has shown it to be useful for detection of organic such as organic carbon and amino acids, among others. SuperCam and SHERLOC (NASA Mars2020 Rover) will also incorporate this technique in their search for evidence of past or present life on Mars (Beegle et al., 2015; Wiens et al., 2016). SHERLOC utilizes LIF as a supporting tool for selection of targets with possible organics via fast mapping. Subsequently, Raman spectroscopy will be able to determine the mineralogy and possible existence of biosignatures (Beegle et al., 2015).

XRD allows the user to obtain mineral identification and structural characterization, and is commonly used for crystallography and mineralogy (Klein, 2008). In space, ChemMin, onboard the MSL Curiosity rover, combines XRD with X-ray fluorescence (Bish et al., 2013). The ChemMin system can identify and quantify the minerals present in rocks and soil in order to understand the habitability of Mars. 
Other supportive methods such as scanning electron microscopy (SEM-EDS) allow us to analyze the mineralogic composition which, in combination with the in situ petrological description and in lab optical mineralogy study, provides information about regolith material source, petrological composition, identification of weathering and hydrothermal processes affecting the Martian rocks. A summary of the techniques used to determine mineral and elemental composition, detect organics, and deduce the geological context is presented in Table 1.

Table 1. Comparison of the capabilities of the 5 systems employed in this investigation. (RLS=Raman Laser Spectrometer), (ChemCam=Chemistry and Camera), (Sherloc=Scanning Habitable Environments with Raman \& Luminescence for Organics \& Chemicals), (CheMin= Chemistry and Mineralogy), (MSL=Mars Science Laboratory)

\begin{tabular}{|c|c|c|c|c|c|c|}
\hline $\begin{array}{l}\text { Laboratory } \\
\text { Technique }\end{array}$ & $\begin{array}{c}\text { Mineral } \\
\text { Identification }\end{array}$ & $\begin{array}{c}\text { Elemental } \\
\text { Composition }\end{array}$ & $\begin{array}{l}\text { Organic } \\
\text { detection }\end{array}$ & $\begin{array}{c}\text { Geological } \\
\text { Context }\end{array}$ & $\begin{array}{c}\text { Laboratory } \\
\text { instrumentation } \\
\text { location in this } \\
\text { study }\end{array}$ & $\begin{array}{c}\text { Rover } \\
\text { Instrument } \\
\text { Equivalent }\end{array}$ \\
\hline $\begin{array}{c}\text { Raman } \\
\text { Spectroscopy }\end{array}$ & Yes & $\begin{array}{l}\text { Potentially } \\
\text { (only major } \\
\text { elements) }\end{array}$ & Yes & $\begin{array}{c}\text { Yes } \\
\text { (mapping) }\end{array}$ & $\begin{array}{c}\text { Royal Ontario } \\
\text { Museum }\end{array}$ & $\begin{array}{c}\text { RLS } \\
\text { (ExoMars) } \\
\text { SuperCam } \\
\text { (Mars 2020) } \\
\text { Sherloc } \\
\text { (Mars2020) }\end{array}$ \\
\hline $\begin{array}{l}\text { Micro- } \\
\text { imaging }\end{array}$ & Yes & No & Yes & Yes & York University & $\begin{array}{c}\text { CLUPI } \\
\text { (ExoMars) }\end{array}$ \\
\hline XRD & Yes & No & No & Potentially & $\begin{array}{c}\text { Royal Ontario } \\
\text { Museum }\end{array}$ & $\begin{array}{c}\text { CheMin } \\
\text { (MSL) }\end{array}$ \\
\hline LIBS & No & Yes & Potentially & $\begin{array}{c}\text { Yes } \\
\text { (mapping) }\end{array}$ & York University & $\begin{array}{c}\text { ChemCam } \\
\text { (MSL) } \\
\text { SuperCam } \\
\text { (Mars 2020) }\end{array}$ \\
\hline LIF & Potentially & No & Yes & No & York University & $\begin{array}{c}\text { Sherloc } \\
\text { (Mars 2020) }\end{array}$ \\
\hline SEM-EDX & $\begin{array}{c}\text { Yes } \\
\text { (Imaging) }\end{array}$ & $\begin{array}{c}\text { Yes } \\
\text { (Qualitative) }\end{array}$ & Yes & No & York University & \\
\hline
\end{tabular}

\section{Geology of the site and its analogy with Mars}


In the Dhofar region a pre-rift, syn-rift and post-rift sequence ranging from Upper Cretaceous prerift sediments until Upper Middle Miocene post-rift deposits units can be found. These series involve three sedimentary groups (Roger et al., 1989): The Hadhramaut Group, Paleocene to late Eocene in age that overlays in an unconformity over cretaceous strata consisting in shallowmarine carbonate units (Lepvrier et al., 2002); The Dhofar Group, late Eocene, laying unconformably over Hadhramaut Group represented by two limestones units part of a shallow lacustrine to shallow marine deposits (Lepvrier et al., 2002) and the Fars Group, early Miocene, compose by conglomerated and carbonate deposits units (Lepvrier et al., 2002). Figure 1 and 2 show The Paleocene-Miocene stratigraphic units of the Dhofar region Simplified geological map of southern Oman (Dhofar area) (from (Robinet et al., 2013).

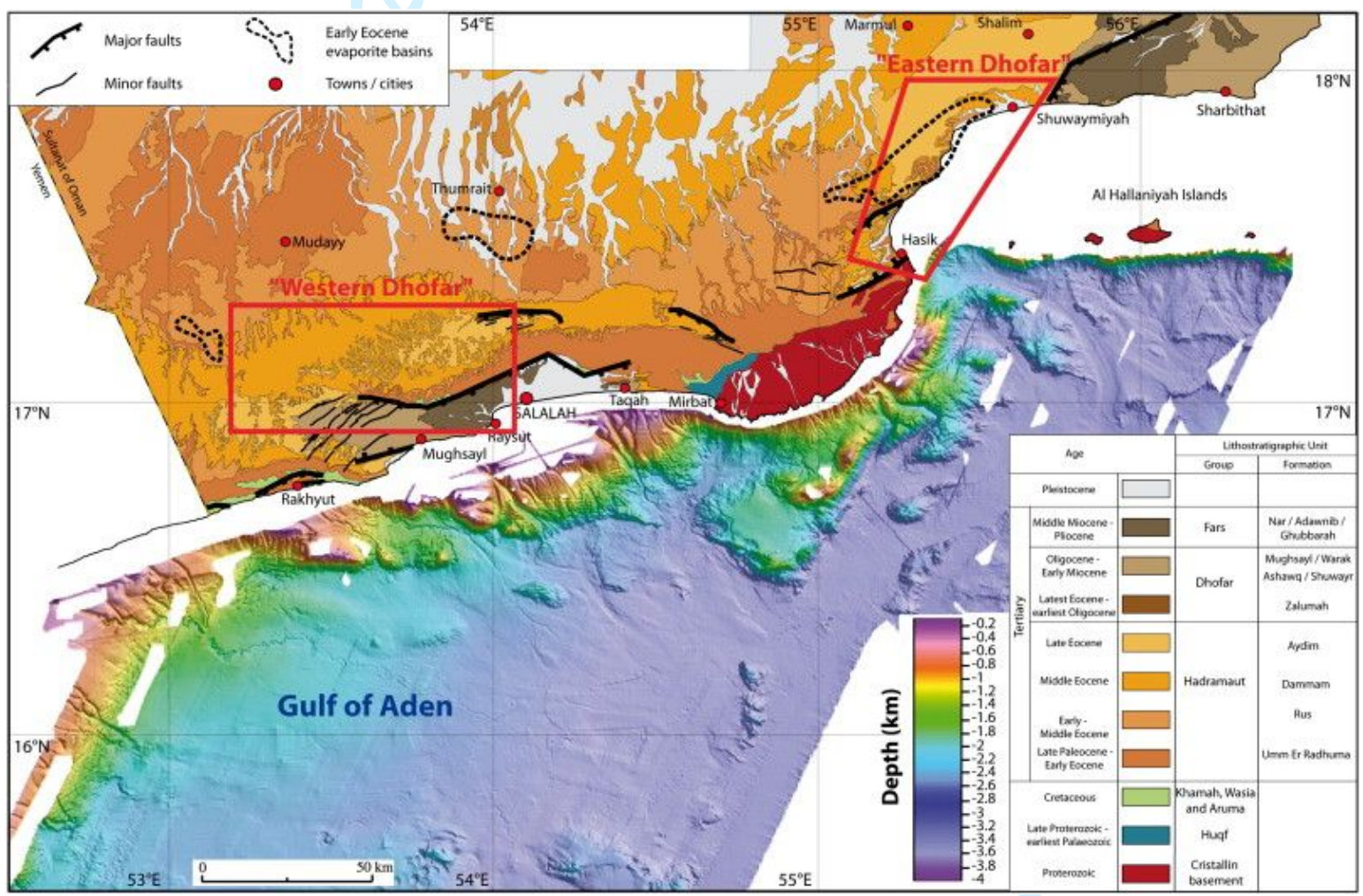

Figure. 1. Simplified geological map of southern Oman (Dhofar area) showing the two studied areas discussed in this paper from (Robinet et al., 2013). (Reproduced by permission of Elsevier). 


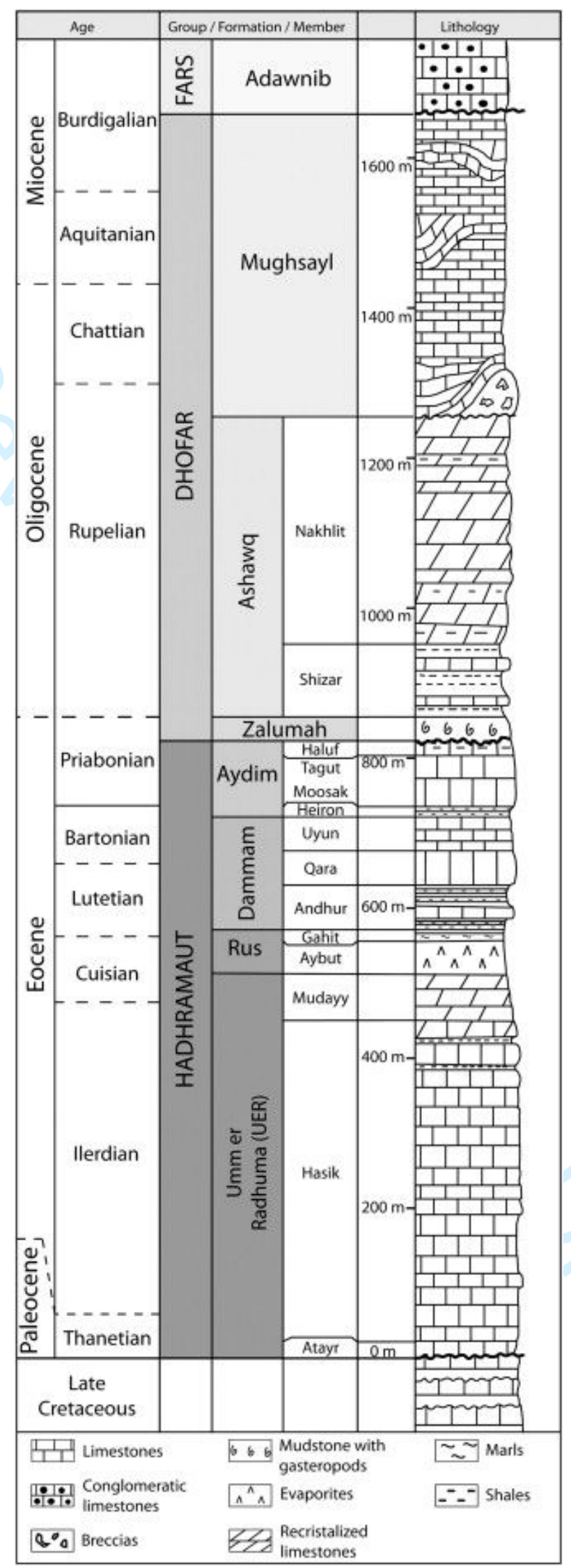

Figure. 2. The Paleocene-Miocene stratigraphic units of the Dhofar region from (Robinet et al., 2013). (Reproduced by permission of Elsevier). 
In the study area, the geological records are register by outcrops of the Huqf Supergroup, in the NE elongated salt basin in south Oman were uplifted blocks become sites of carbonate deposition, whereas basinal transtensional depressions were overlain with black shale and silicyte (Amthor et al., 2005). These belonging to the Ara Fm depositional times (Ramseyer et al., 2013) as can be observed in Figure 3.

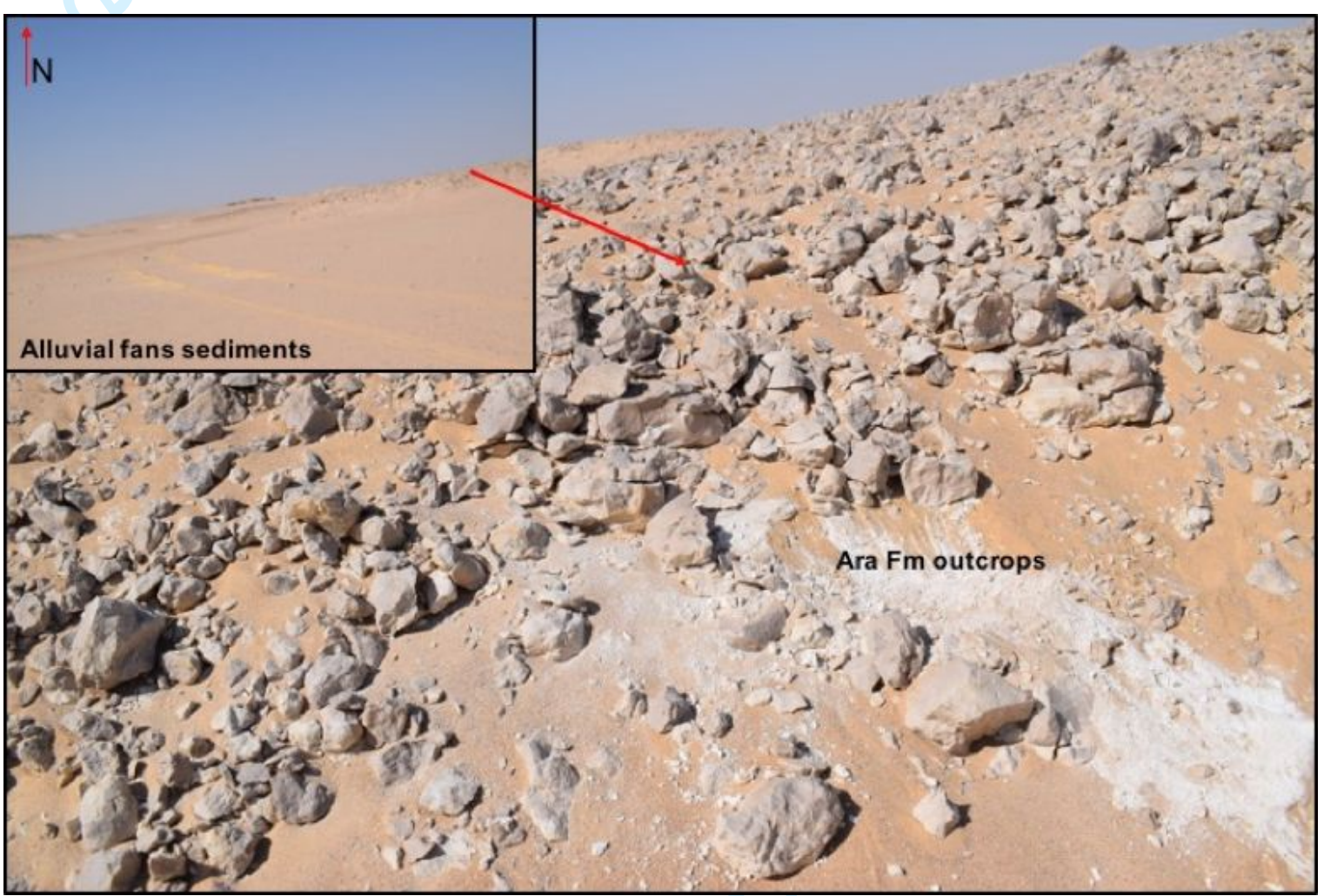

Figure 3. Picture of field site showing the outcrops and alluvial fans deposits from were samples were taking and study in laboratory.

Quaternary deposits of alluvial fans were found during the field study; these unconsolidated sediments are present together with outcrops ranging from $\mathrm{cm}$ up to 1 meter approximately of silicified dolomites and organic-rich laminated chert (silicilyte) belonging to the Ara Fm as observed in Figure 3. The alluvial fans are composed mostly by sand to pebbles to boulders and cemented by poorly sorted rolled clasts covered by thin dark oxidized coating (Yuan et al., 2016) (Figure 3).

The feeding area of the sediments for the alluvial fans comes from the northwest-north region product of erosion and weathering of the Oman mountains outcrops and from the Huqf Supergroup sediments mention before outcropping in the area.

Part of those no consolidated sediments of the alluvial deposits includes volcanic rocks of alkaline to basaltic composition belonging to the volcanic rocks interbedded with the Precambrian- 
Cambrian deposits, limestones and silicified dolomites fragments, and fragments of a hydrothermal altered silicified dolomite-carbonates and volcanic rocks that includes magnetite and sulfides like the remnant product of the hydrothermalism observed before in the Oman mountains (Reuning et al., 2007)

The hydrothermalism was vaguely studied for Dhofar area, its believed to be related to magmatism in part with the intrusion of late-stage veinlets carrying metals of magnetite and sulphides. A possible supergene alteration was also identified on the samples during the petrological description and field studies with secondary mineralization of alunite, coesite and montmorillonite in the sediments together with oxides and secondary chlorite.

The syn-rift deposits observed in the regolith and in the Ara Fm could correspond to possible Martian analogs. The Precambrian-Cambrian carbonates interbedded with volcanic products, and the development of hydrothermal deposits due to active magmatism in a spreading region from the study area can be correlated to similar regions from Mars' surface, such as reported by Michalski et al. (2017). For example, Eridania Basin shows a 3.8 Billion-year record from a spreading area with active high magmatism and signatures of high $\mathrm{Mg}$-Fe rich clay mineral products of hydrothermalism in an ancient lake base with high content of carbon and $\mathrm{Ca}-\mathrm{Fe}-\mathrm{Mg}$ rich carbonates (Michalski et al., 2017). Even though the chemistry of Eridania Basin on Mars is still unknown, strong evidence from infrared spectroscopy and high-resolution imaging suggest that the Eridania Basin contains a complex suite of alteration minerals that likely formed in a hydrothermal seafloor volcanic-sedimentary setting with intrusions of sulfide-rich fluids interacting with ultramafic-mafic volcanic rocks and sediments (Michalski et al., 2017). Even so, more areas in the Martian surface show similarities to geological records from selected places of ancient Earth (Léveillé, 2009). Therefore, our future understanding of Martian geo-chemistry and ancient development of organic rich carbon deposits in similar environments can be improved with the study of these analogs on Earth.

\section{Experimental analysis and setup}

In total, 25 geological samples, mostly consisting of various unconsolidated sediments were collected by the analog astronauts at the different locations where the in-situ experiments were carried out throughout the AMADEE-18 mission (See Figure 4a and 4b). The locations where samples were collected and the field cataloging procedures were conducted are presented in the Field Activity Plans from the mission (Groemer, 2018; Sejkora et al., 2018). The detailed geographical positions of the geo-sampling are available in the online supporting material. 

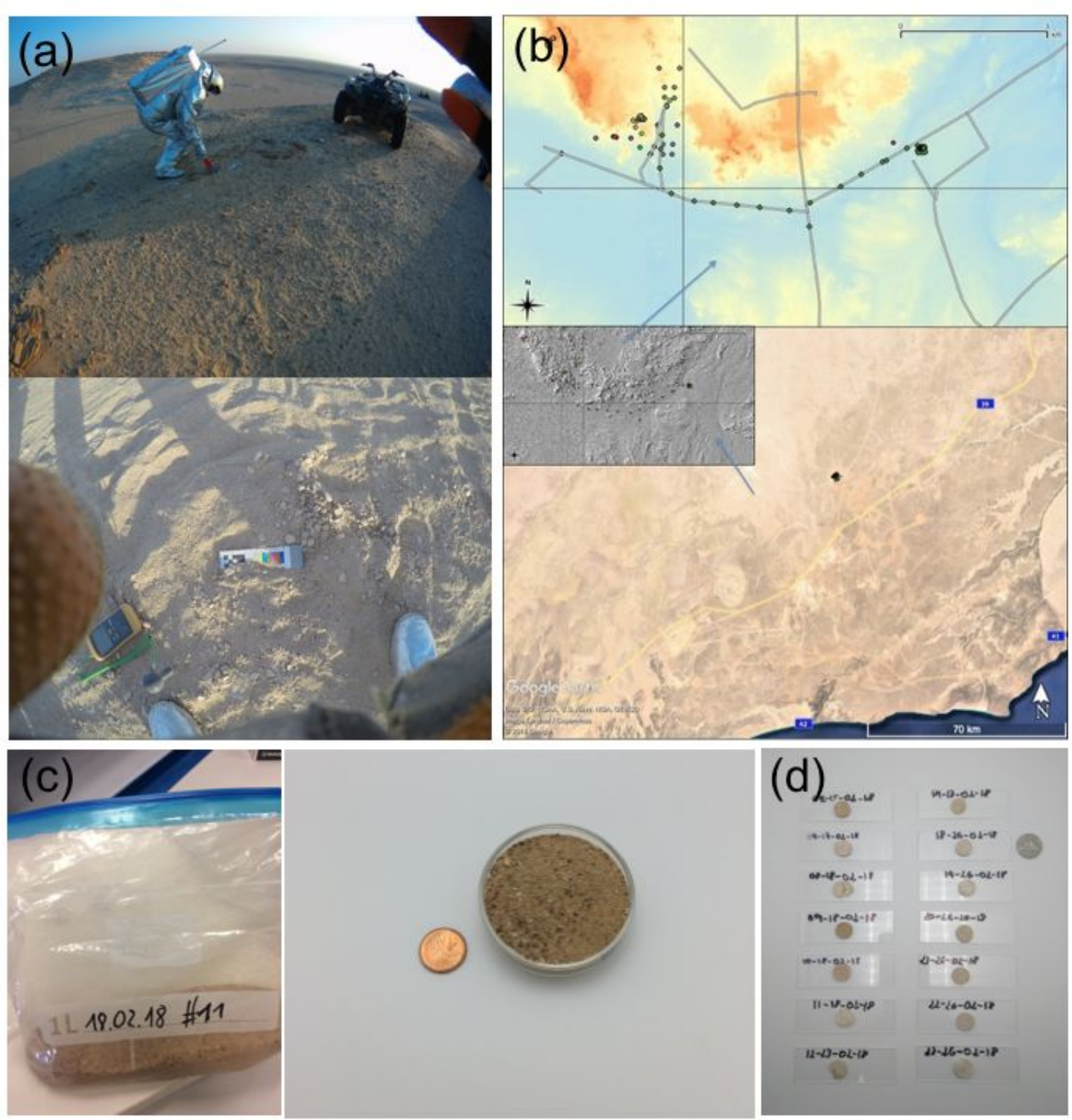

Figure 4. (a) Analog astronauts doing a geo-sampling in the field during the AMADEE-18 mission, (b) Digital Model Elevation (DEM) map of the sampling points with the location, and

Digital Elevation Map (DEM) (the coordinates of sampling location are on the supporting material), (c) example of one the geo-samples cataloged at York University, and (d) pelletized sand samples.

The samples were composed of unconsolidated sediments with grain sizes ranging from $25 \mu \mathrm{m}$ to a few $\mathrm{mm}$ in diameter. For practical reasons, LIBS and SEM-EDS measurements need to have a pelletized sample before carrying out the measurements. The sample preparation was conducted to ensure the same mineral and organic compositional properties. A small amount (5-10 g) from each sample was powdered manually in an agate mortar and sieved to obtain particles ranging from $45-150 \mu \mathrm{m}$ in size. Powders were mixed with $1 \mathrm{ml}$ of distilled water and compressed. These humidified pellet samples were left to dry by evaporation at high vacuum and room temperature. 
This resulted in the formation of stable pellets. To carry out the measurements, the pellet was glued to a microscope slide for easy handling (See Figure 4c).

Micro-Raman measurements were made with a Horiba Lab-RAM Aramis Raman spectrometer. The analyses employed a $532 \mathrm{~nm} 50 \mathrm{~mW}$ laser focused to a $1.3 \mu \mathrm{m}$ spot (FWHM). The spectrometer configuration used a $100 \mu \mathrm{m}$ slit, and a 1200 grooves $/ \mathrm{mm}$ diffraction grating. The location of the points to be analyzed were selected by the operator, along with several automatic mappings. A total of 40 different points per sample were acquired. The routine for obtaining the spectra was: selecting the point, taking a preview spectrum (fast measurement for good signal and focusing condition), and finally acquiring the spectra. The measurement conditions (acquisition and accumulations) for the manual location were varied from point to point ranging between several second to several minutes. The automatic mapping conditions per sample were 20 points separated $0.05 \mathrm{~cm}$. Measurements at each point are a cumulative spectrum of five $10 \mathrm{~s}$ exposures. Spectra were corrected following the standard procedure available on the OPUS software from Bruker. A background subtraction was done using the Rubberband correction method and 65 baseline points. The normalization to the maximum value $=1$ was carried out and spectral smoothing was used when the spectra was noisy for band identification. The LevenbergMarquardt curve fitting was done when in some of the spectra because several Mineral Raman bands were overlapping. Mineral identification was performed by comparison to the RRUFF Database using Crystal Sleuth (Downs et al., 2015; Laetsch and Downs, 2006). Voight fittings were used to deconvolute the main spectral features when the Raman bands of several minerals overlapped.

XRD measurements were carried out with a Bruker D8 Advance Diffractometer equipped with a two-circle goniometer setup and $\mathrm{CuK}_{\alpha}$ radiation source. The system was operated with a voltage generator of $40 \mathrm{kV}$ and current of $40 \mathrm{~mA}$. The data was collected using a Ni-filter, low background plate, and a LYNXEYE detector. The XRD diffractograms were acquired in range $10<2 \theta^{\circ}<70$ with a step size of $0.02^{\circ}$ and acquisition time of $1 \mathrm{~s}$ per step and a rotation spin of 15 per minute. Analysis of resulting diffractograms was performed using the XPowder 2004.04.71 software with PDF-2 (2010) and the American Mineralogist Crystal Structure Database (AMCSD) crystallographic databases. A background correction for each diffractogram was achieved with the Splin-autoroller and polynomial tools available XPowder 2004.04.71 that allows to calculate a background polynomial subtraction function (Martin, 2004). XRD mineral quantification, and theoretical density determination of the mixture was achieved using the reference intensity ratio (RIR) from pattern matching results with XPowder 2004.04.71 (Martin, 2004).

The micro-imaging analyses and petrological descriptions were made with a standard binocular Zeiss microscope. 
Laser-induced fluorescence measurements were carried out using a $266 \mathrm{~nm}$ Raman-LIF system designed by (Eshelman et al., 2015, 2014) satisfying selected requirements of a putative flightworthy instrument. The excitation power was provided by a quadrupled Team Photonics diodepumped solid state Nd:YAG laser with a $0.6 \mathrm{~ns}$ pulse width and $13.8 \mu \mathrm{J}$ pulse energy at $1000 \mathrm{~Hz}$. The acquisition system was composed of an Andor Shamrock 163 spectrometer. A 600 lines $/ \mathrm{mm}$ grating allowed for an observation window between 270 to $550 \mathrm{~nm}$. The spectrometer is coupled to an intensified, cooled CCD (Andor iStar 334T). The $1 \mathrm{~cm}$ long, 20-point LIF measurements are each an accumulation of 40 spectra with $0.01 \mathrm{~s}$ exposures. The spectral corrections were done in a same way as the Raman analysis.

The elemental composition of the AMADEE-18 geo-samples was measured using a Vega TESCAN Scanning Electron Microscope (SEM) equipped with a Bruker Quantax energy dispersive X-ray (EDS) detector. The beam voltage used for secondary electron imaging (SEI) and backscatter electron imaging (BSE), as well as EDS spectra acquisition, was $10 \mathrm{kV}$. SEMEDS data were collected on the pelletized sand samples without any coating.

LIBS measurements were achieved with a breadboard system. Plasma excitation was obtained with a $1064 \mathrm{~nm}$ Quantel ULTRA Nd:YAG laser with $10 \mathrm{~mJ}$ pulse energy and $10 \mathrm{~ns}$ pulse width, focused to a $33 \mu \mathrm{m}$ spot (FWHM). The peak power density at the target is on the order of 100 $\mathrm{GW} / \mathrm{cm}^{2}$. The light produced from the plasma is collected through an off-axis $\mathrm{f} / 7$ collection system and delivered via fiber to the Andor ME5000 echelle spectrograph combined with the ICCD Andor iStar 334T camera (covering 230-850 nm). The spectrometer was wavelength calibrated using an Ocean Optics HG1 Calibration Light Source and intensity calibrated using an Ocean Optics DH-3P-CAL Calibration Light Source. Pelletized samples were used for LIBS analysis. Each LIBS measurement consists of 15 cumulative spectra with $0.1 \mathrm{~s}$ exposures (one spectrum per laser shot, for a total of 15 shots). An intensity correction was performed using the standard ANDOR Solis software procedure for the ME5000. Identification of element present within the spectra were carried with the Solis software and manual identification with the NIST Spectral Lines Database (National Institute of Standards and Technology, 2016).

\section{Results}

\section{Field samples petrological description}

14 of the most representative regolith samples from the Quaternary alluvial fans sediments, silicified veinlets intruding Ara Fm outcrops, and the silicified dolomite and carbonate rocks samples from the Ara Fm outcrops were selected in order to describe the mineralogy and 
petrology. These studies were later used to compare with the data acquired from LIBS, Raman and SEM-EDS laboratory analyses.

A microscope magnifier Zeiss lens was used for the petrological description. Varying grain sizes from sand to pebbles and gravel were observed (Figure 5 and 6).

During the petrological study of the sediment samples, sand and pebble sizes of calcite, dolomite, silicified dolomite rocks and quartz rocks fragments were observed. These present rounded to sub-rounded shapes with sizes up to $1 \mathrm{~mm}$. All of them show an irregular oxidized coating on their surfaces. They represent more of the $80 \%$ of the sediment components.

In minor quantities, less than $10 \%$, sub-rounded to sub-angular fragments of volcanic rocks from intermediate to basic composition (andesites and basalts) are present. These rocks mostly show an altered matrix, with presence of secondary clay alteration (possible montmorillonite and coesite), plagioclase, amphiboles, pyroxenes crystal observed embedded in matrix.

Sediments also show single crystals in less than $8 \%$ and 0.5 to $0.1 \mathrm{~mm}$ sizes range belonging to unidentified feldspars in angular to sub-angular crystals; unidentified plagioclases, prismatic subangular crystals, many of them with clay alteration on their borders. Volcanic quartz sub-rounded to rounded with dark inclusions, prismatic crystals of amphiboles, chloritized and with presence of oxides inclusions on their borders, and transverse basal sections of pyroxenes, prismatic crystal of chlorite and zircons were also identified.

Between 2 to $5 \%$ oxides and sulfides were present in the sediments. Alunite was observed likely as replacement of sulfides, possible pyrite, in small sizes (less than $0.5 \mathrm{~mm}$ ) of silicified veinlets (Figure 5 and 6)

Samples belonging to silicified veinlets and silicified dolomite Ara Fm sediments were also described. The first ones show a matrix of fine microcrystalline white silica, with presence of anorthoclase plagioclase crystals in sizes ranging from less than $0.1 \mathrm{~mm}$ up to $0.5 \mathrm{~mm}$, which were fractured and rotated; showing evidence of flow movement in the matrix. Magnetite and sulfides were also observed. For the silicified dolomite rock fragments, a fine microcrystalline matrix of dolomite replaced by silica was clear via microscope mineral identification. Some of them show a small zebra pattern, related to possible hydrothermal activity as can be observed in Figure 5 and 6. 

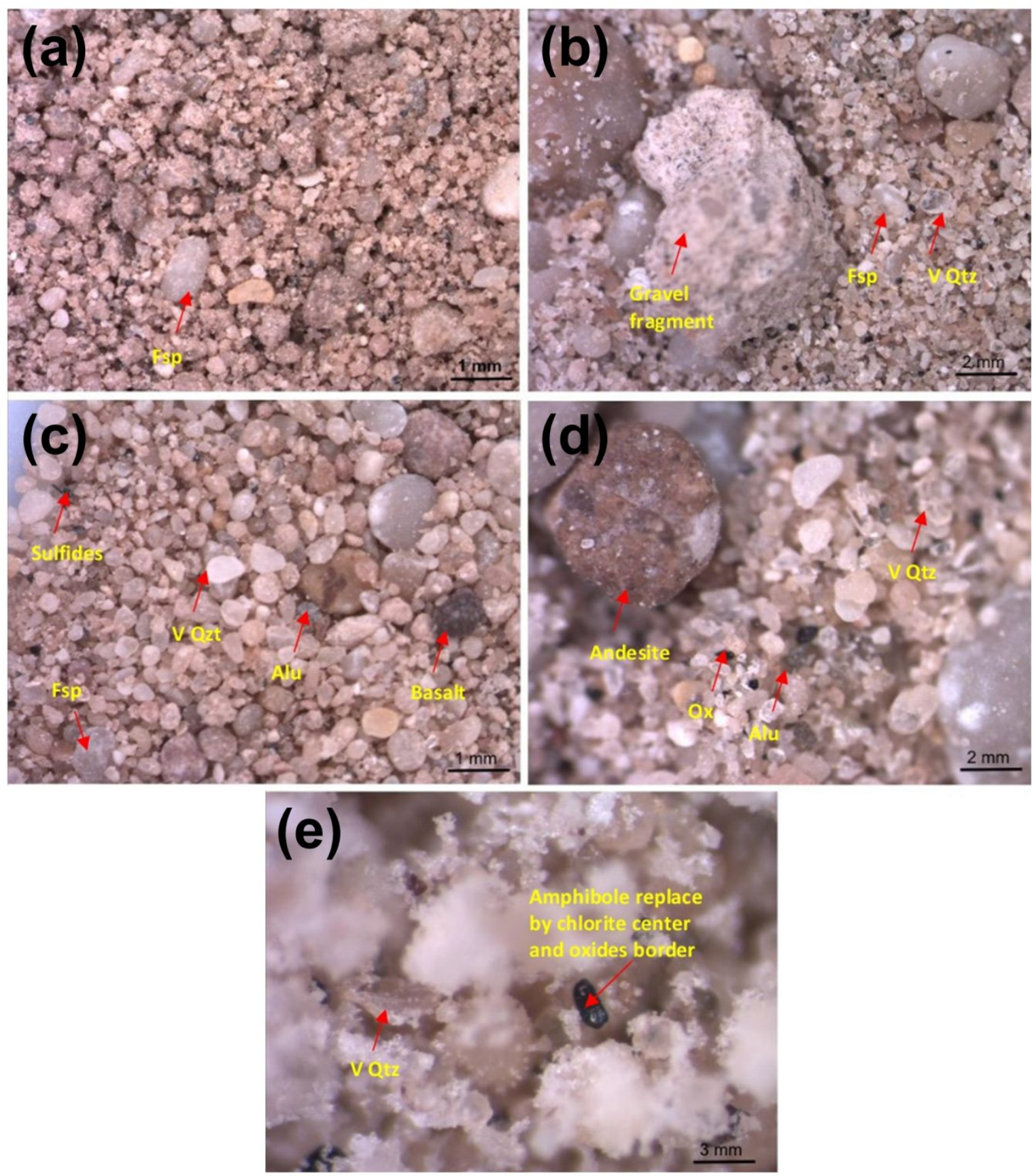

Figure 5. Magnified images of the alluvial fan sediments and sand to gravel size material. (a) Dolomites, silicate, carbonate clasts with feldspar crystals; (b) sand with presence of volcanic quartz, feldspar, disseminated oxides and gravel size clast; (c) rounded volcanic quartz, dolomite clasts, rounded basalt clast and alunite and feldspar crystals; (d) andesite sub-rounded clast with abundant presence of volcanic quartz, and oxides and disseminated alunite crystals;

(e) amphibole in fine grained silica with chloritized mineralization in center and oxides in borders. Abbreviations: Fsp (feldspar), V Qtz (volcanic quartz), Alu (alunite) and Ox (oxide). 

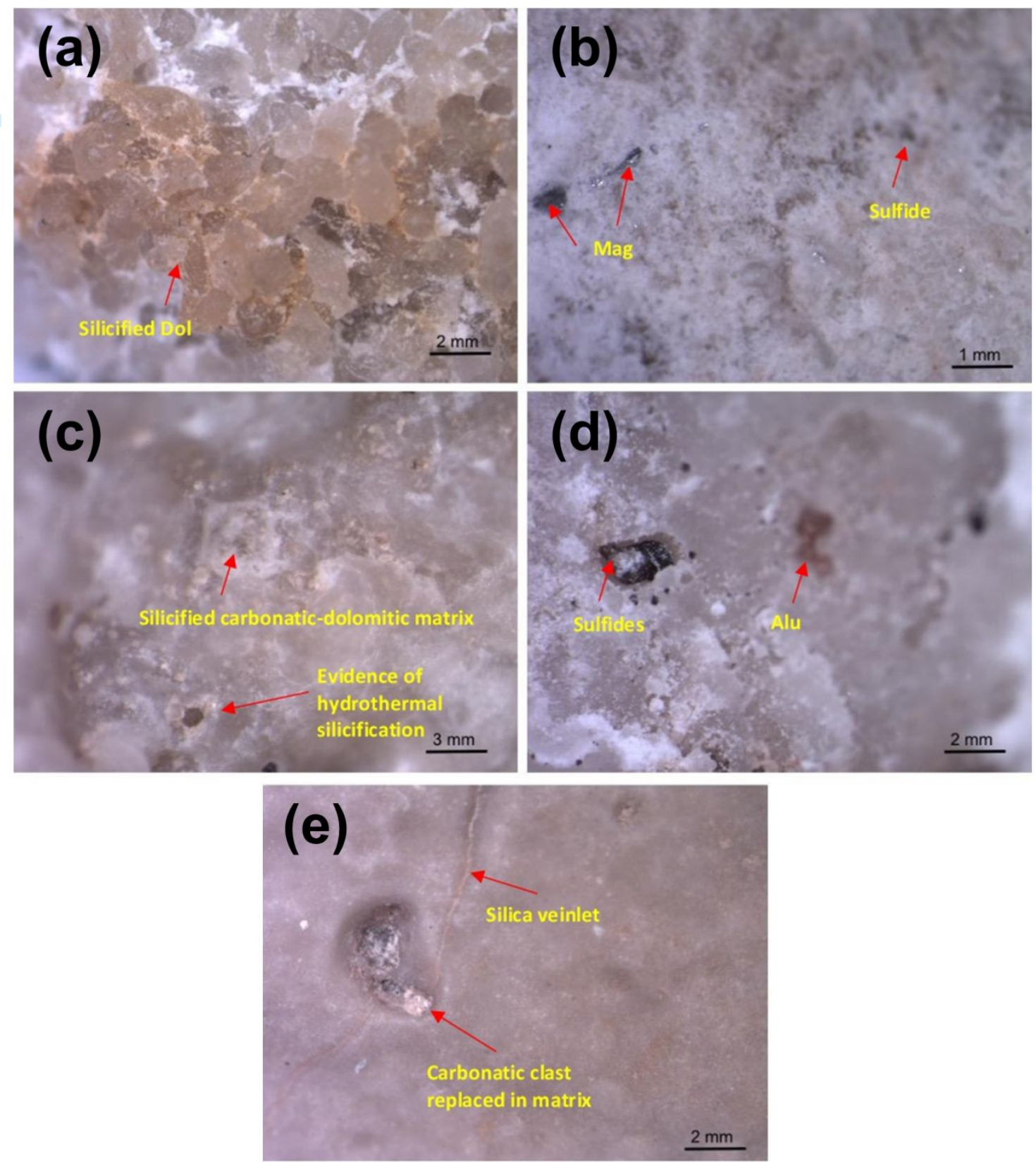

Figure 6. Magnified images of the alteration processes. (a) The silicate replacing dolomite rock from Ara Fm with oxide coating on the surface; (b) silica vein intruded in Ara Fm carrying magnetite and sulfides; (c) silicate replacing carbonate rocks from Ara Fm (possible evidence of supergen activity); (d) random dissemination of oxides and alunite crystals in silica vein matrix; (d) fine to very fine silica matrix replacing carbonate rocks (details of carbonate clast and silica veins in process of replacement can be observed). Abbreviations: dolomite (Dol), magnetite (Mag), and alunite (Alu).

\section{Raman Analysis}

The mineralogical composition results are listed in Table 2 following the ordering of Dana's classification method (Palache et al., 1952). Figure 7 shows representative Raman spectra 
obtained from the samples. Identification of mineral species is done using the RRUFF Database within the Crystal Sleuth software (Downs et al., 2015; Laetsch and Downs, 2006). The following references for each minerals were considered alongside the spectral analyses: oxides (Balachandran and Eror, 1982; Markovski et al., 2017; Wang et al., 2004), carbonates (Buzgar and Apopei, 2009; Rull-Perez and Martinez-Frias, 2003), pyroxenes (Huang et al., 2000; Wang et al., 2001), feldspar (Freeman et al., 2008; Lalla et al., 2019, 2015), clays (Apopei and Buzgar, 2010; Black and Hynek, 2018; E.A. Lalla et al., 2016), and organics (Ferrari, 2007). The organics present in the main Raman bands in the range of 2800 to $3000 \mathrm{~cm}^{-1}$ correspond to $\mathrm{C}-\mathrm{H}$ bonding and the other less intense bands near $1300 \mathrm{~cm}^{-1}$ correspond to C-C vibrations (Beegle et al., 2015).

Table 2. Micro-Raman mineral and other material detection on the different sampling points from AMADEE-18 Mission. $\mathrm{X}$ indicates that the mineral was found to be present in the respective sample.

\begin{tabular}{|c|c|c|c|c|c|c|c|c|c|c|c|c|c|c|c|}
\hline & \multicolumn{15}{|c|}{ Samples } \\
\hline Mineral & $\frac{n}{\frac{1}{d}}$ & $\stackrel{\bar{n}}{8}$ & $\frac{1}{\frac{1}{0}}$ & $\frac{\infty}{1}$ & $\frac{\infty}{8}$ & $\frac{\infty}{\grave{c}}$ & $\stackrel{\infty}{I}$ & 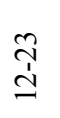 & $\frac{m}{\dot{I}}$ & 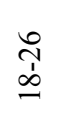 & $\begin{array}{l}\stackrel{\sim}{2} \\
\stackrel{2}{2}\end{array}$ & $\begin{array}{l}\text { ते } \\
\text { ஸे }\end{array}$ & $\begin{array}{l}\stackrel{\sim}{\grave{N}} \\
\stackrel{\sim}{\sim}\end{array}$ & 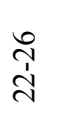 & $\begin{array}{l}\stackrel{2}{N} \\
\stackrel{\sim}{2}\end{array}$ \\
\hline Magnetite & $\mathrm{X}$ & $\mathrm{X}$ & & & & $\mathrm{X}$ & & $\mathrm{X}$ & & $\mathrm{X}$ & & & $\mathrm{X}$ & $\mathrm{X}$ & $\mathrm{X}$ \\
\hline Hematite & & & & & 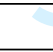 & $X$ & $\theta$ & $X$ & $X$ & $X$ & $\mathrm{X}$ & & & $X$ & $X$ \\
\hline Goethite & & & & & & $X$ & & 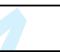 & & & & & & & \\
\hline Anatase & & $\mathrm{X}$ & & & & & $\mathrm{X}$ & 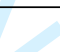 & & & $\mathrm{X}$ & $X$ & & $X$ & \\
\hline Chromite & & & & & & & & 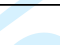 & & & & $\mathrm{X}$ & & & \\
\hline Quartz & $\mathrm{X}$ & $\mathrm{X}$ & $X$ & $\mathrm{X}$ & $\mathrm{X}$ & $\mathrm{X}$ & $\mathrm{X}$ & $\mathrm{X}$ & $X$ & $X$ & $\mathrm{X}$ & $\mathrm{X}$ & $\mathrm{X}$ & $\mathrm{X}$ & $\mathrm{X}$ \\
\hline Calcite & $\mathrm{X}$ & $\mathrm{X}$ & $\mathrm{X}$ & $\mathrm{X}$ & $\mathrm{X}$ & $\mathrm{X}$ & $\mathrm{X}$ & $X$ & $X$ & $X$ & $\mathrm{X}$ & $\mathrm{X}$ & $\mathrm{X}$ & $\mathrm{X}$ & $\mathrm{X}$ \\
\hline Dolomite & & $X$ & & & & & & $X$ & & 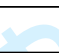 & & & $\mathrm{X}$ & & \\
\hline Titanite & & & & & & $X$ & & & 8 & & & & & & \\
\hline Olenite & & & & & & & & & & & & $X$ & & & \\
\hline Enstatite & & $X$ & & & & & & & & 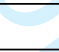 & $X$ & & & & \\
\hline Diopside & & & & & & & $X$ & & & & $X$ & $\Delta$ & & & \\
\hline Epidote & & & & & & & & & & & P & & $\mathrm{X}$ & & $\mathrm{X}$ \\
\hline Microcline & & & & $X$ & & & & $X$ & & & 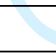 & 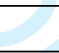 & 8 & $X$ & \\
\hline Orthoclase & & & & & & & & & & & & 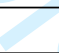 & $\mathrm{X}$ & & \\
\hline Sanidine & & & & $\mathrm{X}$ & $\mathrm{X}$ & $X$ & $X$ & & & & & $X$ & & & \\
\hline Albite & & $\mathrm{X}$ & & & $\bar{X}$ & $\mathrm{X}$ & & $\mathrm{X}$ & $X$ & & $X$ & $X$ & $\mathrm{X}$ & & $\mathrm{X}$ \\
\hline Andesine & & & & & $X$ & & & $X$ & & & $\mathrm{X}$ & & $P$ & 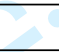 & \\
\hline Labradorite & $X$ & & & & & & & & & & & & & & $X$ \\
\hline Clays & & & & & & $\mathrm{X}$ & & & & & & & & 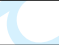 & 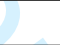 \\
\hline $\begin{array}{l}\text { Carbonaceous } \\
\text { Material and } \\
\text { organics }\end{array}$ & $\mathrm{X}$ & $\mathrm{X}$ & $X$ & $\mathrm{X}$ & $\mathrm{X}$ & $\mathrm{X}$ & $\mathrm{X}$ & $\mathrm{X}$ & $\mathrm{X}$ & $\mathrm{X}$ & $\mathrm{X}$ & $\mathrm{X}$ & $\mathrm{X}$ & $\mathrm{X}$ & $\mathrm{X}$ \\
\hline
\end{tabular}




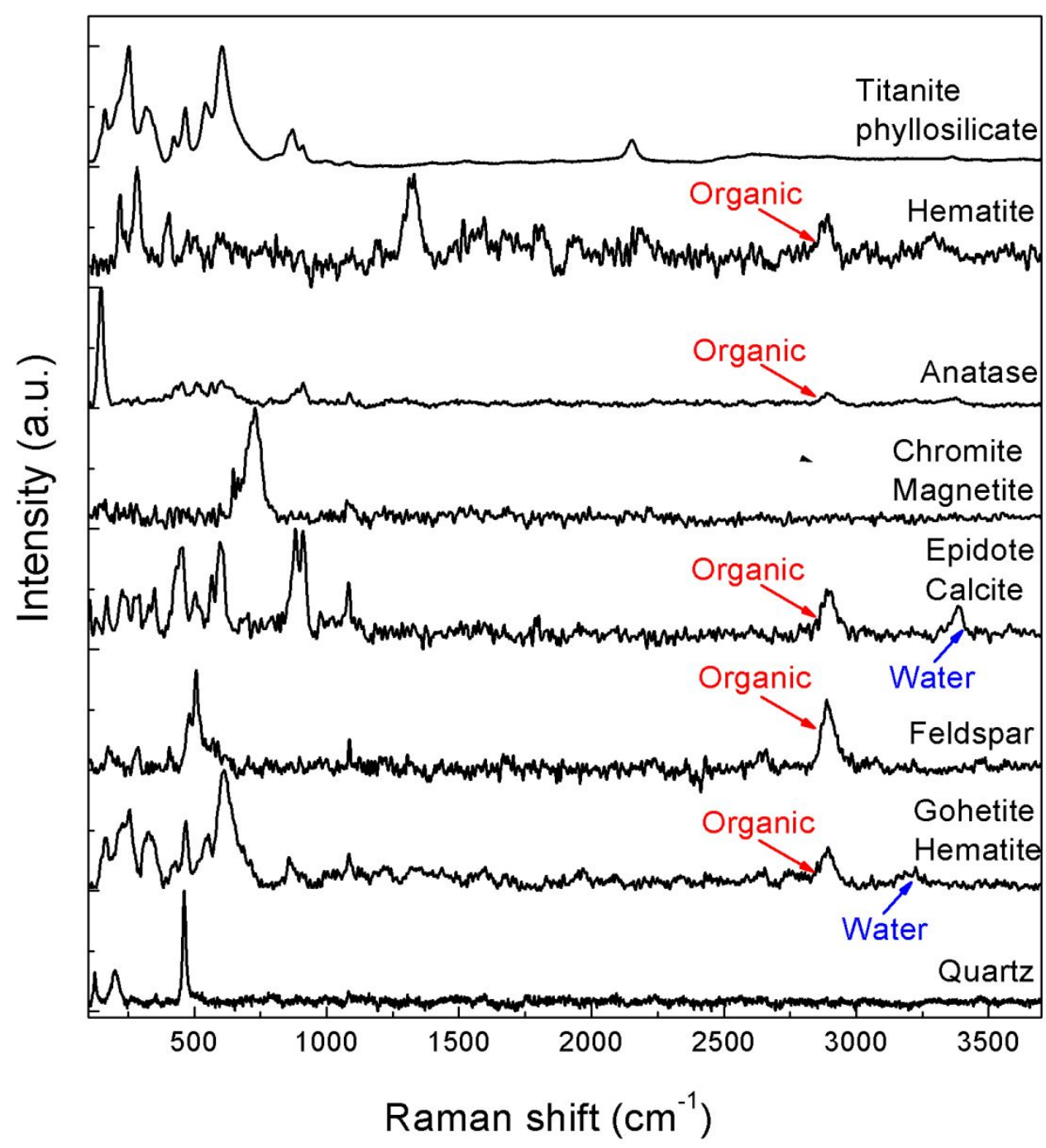

Figure 7. Micro-Raman spectra of the most significant mineral phases detected.

\section{XRD analysis}

The minerals found within the collected samples using XRD are compiled in Table 3. Figure 8 compiles the XRD diffractograms of the different sampling points and the higher concentration minerals detected on the different samples are also indexed in the figure. The detailed mineral quantification of each transect point is attached as supporting material in weight percent (wt $\%$ ) including all the minor minerals. 
Table 3. XRD mineral detection on the different sampling points from AMADEE-18 Mission. $\mathrm{X}$ corresponds to the detected mineral in each collected sample.

\begin{tabular}{|c|c|c|c|c|c|c|c|c|c|c|c|c|c|c|}
\hline & \multicolumn{14}{|c|}{ Samples } \\
\hline Mineral & $\frac{n}{d}$ & $\frac{7}{\frac{1}{0}}$ & $\frac{\infty}{1}$ & $\frac{\infty}{1}$ & $\frac{\infty}{1}$ & $\stackrel{\infty}{\stackrel{D}{\Xi}}$ & 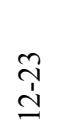 & $\frac{m}{ \pm}$ & 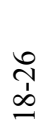 & $\begin{array}{l}\stackrel{1}{1} \\
\stackrel{2}{\Omega}\end{array}$ & $\begin{array}{l}\stackrel{0}{~} \\
\text { ஸे }\end{array}$ & $\stackrel{\stackrel{N}{N}}{\stackrel{N}{N}}$ & $\begin{array}{l}\text { İ } \\
\text { ते }\end{array}$ & $\begin{array}{l}\text { N } \\
\stackrel{\sim}{N}\end{array}$ \\
\hline Iron-Oxides & & & & & $\mathrm{X}$ & & & & & & & & & \\
\hline Anatase & $\mathrm{X}$ & & & & & & & & & & & & $\mathrm{X}$ & \\
\hline Rutile & $\mathrm{X}$ & & & & & & & & & & & & $\mathrm{X}$ & \\
\hline Quartz & 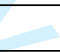 & $\mathrm{X}$ & $\mathrm{X}$ & $\mathrm{X}$ & $\mathrm{X}$ & $\mathrm{X}$ & $\mathrm{X}$ & & $\mathrm{X}$ & $\mathrm{X}$ & $\mathrm{X}$ & $\mathrm{X}$ & $\mathrm{X}$ & $\mathrm{X}$ \\
\hline Calcite & 4 & $X$ & $X$ & $X$ & $X$ & $X$ & $X$ & $X$ & $X$ & $\mathrm{X}$ & $X$ & $\mathrm{X}$ & $X$ & $\mathrm{X}$ \\
\hline Dolomite & - & $X$ & $\mathrm{X}$ & $X$ & & $\mathrm{X}$ & & & & $\mathrm{X}$ & & & & \\
\hline Ferrosilite & . & & & & & & & $X$ & & & & $\mathrm{X}$ & & \\
\hline Olenite & & ter & & & & & & & & & $X$ & & & \\
\hline Diopside & $\mathrm{X}$ & & & & & & & & & & & & & \\
\hline Pigeonite & & & & & & & $\mathrm{X}$ & & & & & & & \\
\hline Enstatite & & & $\mathrm{X}$ & 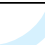 & & & & $\mathrm{X}$ & & & & & & \\
\hline Epidote & & & & 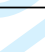 & t & & & & & & & & & $\mathrm{X}$ \\
\hline Pyrope & & & $\mathrm{X}$ & & 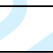 & & & & & & $\mathrm{X}$ & & & \\
\hline Coesite & & & & & 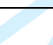 & & $\mathrm{X}$ & & & & & & & \\
\hline Olivine & & & & & 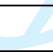 & $X$ & & & $\mathrm{X}$ & & & & & \\
\hline Feldspar & & & & & 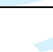 & & 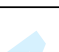 & & $\mathrm{X}$ & & & & & $\mathrm{X}$ \\
\hline Anorthoclase & & & & & & & 1 & & & & & & $X$ & \\
\hline Orthoclase & & & & $X$ & & & 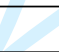 & & & & & & & \\
\hline Sanidine & & & & & & & $\mathrm{X}$ & & & & & & & \\
\hline Anorthite & & & & & $\mathrm{X}$ & & C. & 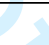 & & $X$ & & & & \\
\hline Albite & $\mathrm{X}$ & & $\mathrm{X}$ & $\mathrm{X}$ & & & & $\mathrm{X}$ & & & & $\mathrm{X}$ & & \\
\hline Bytownite & & & & & & & & & 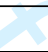 & & $X$ & & & \\
\hline Andesine & $\mathrm{X}$ & $\mathrm{X}$ & & & & & & & C & & & & & \\
\hline Labradorite & $\mathrm{X}$ & & & & & & & $\mathrm{X}$ & 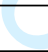 & & & & & \\
\hline
\end{tabular}




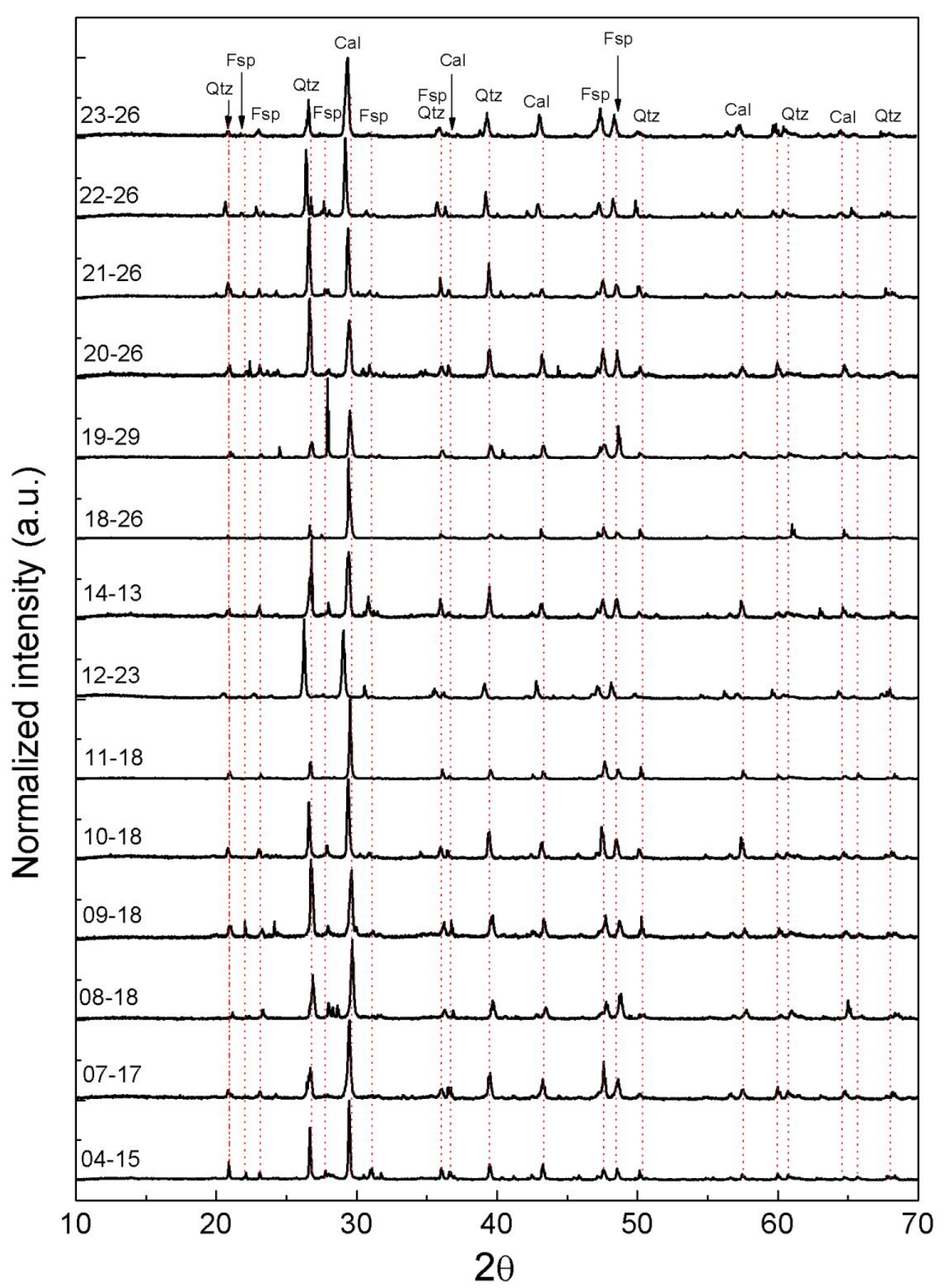

Figure 8. X-Ray diffractogram of the selected transect points from the AMADEE-18 Mission. The minerals shown are the higher concentration obtained from the quantification (see supporting materials). Abbreviations: quartz (Qtz), calcite (Cal) and feldspar (Fsp). 


\section{Laser Induced Fluorescence}

A $1 \mathrm{~cm}$ long, 20-point LIF measurement was carried out on unprocessed sediment. Results of the LIF measurements for the different sampling points are shown in Figure 9a-d. The most intense LIF bands for organic detection are located between 300 to $450 \mathrm{~nm}$ (Eshelman et al., 2015, 2014). The spectra from the organics detected at the collected samples were compared with the internal PIL (Planetary Exploration Instrumentation Laboratory) database (Cote et al., 2018; Lymer, 2018). The results coincide with previous analyses of amino-acids like tyrosine and possibly tryptophan. Figure 9e shows a comparison between the different amino-acids used as standards and the detected organics from AMADEE-18 mission. The minerals detected coincide with carbonates (dolomite and calcite) and silica (quartz) LIF spectra from the PIL database. The dolomite is clearly differentiable on the spectra considering broad bands at $\sim 350$ and $\sim 460 \mathrm{~nm}$. The quartz presents a weak band at $\sim 325$ and the strongest broad band between 450 to $475 \mathrm{~nm}$. Also, Figure 9e. presents some selected bands from the different minerals detected and AMADEE-18 results. Table 4 shows the minerals and organic signature detected for the different samples. The minimum amount of minerals and organic signatures were considered only for more than $15 \%$ of detection of the 20 -point, being in more than 3 points

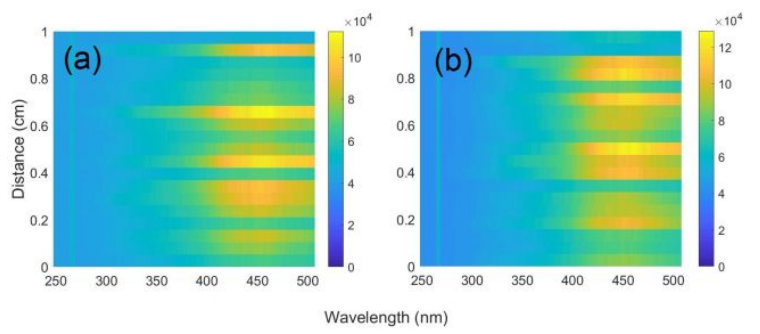

(e)
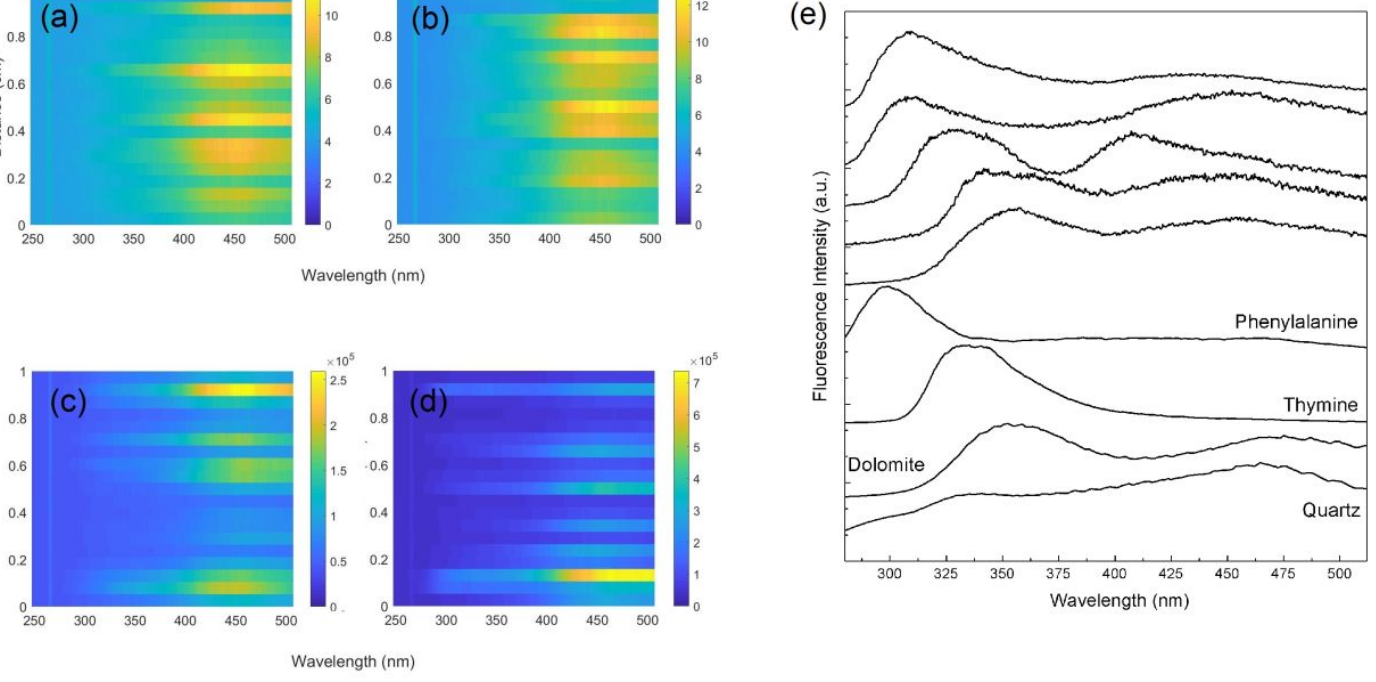

Figure 9. Representative LIF measurements (20 points along a $1 \mathrm{~cm}$ line) from the different sampling points from AMADEE-18: (a) 09-18; (b) 10-18; (c) 12-23; (d) 18-26; (e) selected spectral comparison with some organics and minerals 
Table 4. Main LIF minealogical detection for the different sampling points from AMADEE-18 Mission (20-point mapping of $1 \mathrm{~cm}$ line). $(* *$ The carbonate and organic signatures were considered only for more than $15 \%$ of detection - more than 3 points

\begin{tabular}{|c|c|c|c|c|c|c|c|c|c|c|c|c|c|c|}
\hline 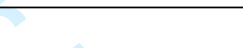 & \multicolumn{14}{|c|}{ Samples } \\
\hline & $\frac{n}{d}$ & $\frac{5}{5}$ & $\frac{\infty}{1}$ & $\frac{\infty}{\frac{1}{8}}$ & $\frac{\infty}{\infty}$ & $\stackrel{\infty}{\stackrel{1}{\Xi}}$ & $\begin{array}{l}\tilde{T} \\
\stackrel{1}{\simeq}\end{array}$ & $\frac{m}{d}$ & $\underset{\sim}{\sim}$ & $\begin{array}{l}\stackrel{2}{\sim} \\
\text { a }\end{array}$ & $\begin{array}{l}\stackrel{0}{N} \\
\text { } \\
\stackrel{\sim}{N}\end{array}$ & $\frac{\mathscr{T}}{\stackrel{1}{N}}$ & 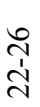 & $\begin{array}{l}\stackrel{0}{\sim} \\
\stackrel{2}{\sim}\end{array}$ \\
\hline $\begin{array}{l}\text { Silicate (Quartz, } \\
\text { Amorphous sand) }\end{array}$ & $\mathrm{X}$ & $\mathrm{X}$ & $\mathrm{X}$ & $\mathrm{X}$ & $\mathrm{X}$ & $\mathrm{X}$ & $\mathrm{X}$ & $\mathrm{X}$ & $\mathrm{X}$ & $\mathrm{X}$ & $\mathrm{X}$ & X & $\mathrm{X}$ & $\mathrm{X}$ \\
\hline $\begin{array}{l}\text { Carbonates } \\
\text { (Calcite or } \\
\text { dolomite) } \\
\end{array}$ & $\mathrm{X}$ & $\mathrm{X}$ & $\mathrm{X}$ & & & & & $\mathrm{X}$ & $X$ & $X$ & $\mathrm{X}$ & $X$ & $\mathrm{X}$ & \\
\hline $\begin{array}{c}\text { Organic } \\
\text { signature** }\end{array}$ & $\mathrm{X}$ & $\mathrm{X}$ & & $X$ & $\mathrm{X}$ & $\mathrm{X}$ & $\mathrm{X}$ & $\mathrm{X}$ & & & $\bar{X}$ & 5 & $\mathrm{X}$ & $\mathrm{X}$ \\
\hline
\end{tabular}

\section{Scanning Electron Microscopy Analysis (SEM-EDS)}

The results of the semi-quantitative EDS analyses are summarized in Table 5. The elemental analysis, representing bulk composition of the mixed powder samples was performed on areas of approximately $10 \mathrm{~mm}^{2}$ on each pellet representing a qualitative approximation of the elemental distribution. The quantification of EDS spectra was performed with the P/B-ZAF QUANTAX analysis strategy (Bruker-Nano, 2011). This is a standard-less, self-calibrating spectrum analysis procedure that makes use of ZAF matrix correction formulas, enabling simple processing of the EDS spectra collected for each sample. Since the accuracy of EDS quantification is relatively low, especially with standard-less quantification, the normalized elemental mass percentages were used to allow comparison within and between samples for the relative elemental concentrations. With these quantifications, a qualitative analysis of the sample elemental composition was performed on the data. Figure 10 shows an example of the elemental distribution and BSE profile of a sample. Most samples appeared relatively homogeneous in BSE images, however, distinct mineral phase boundaries appeared in some samples, as evidenced in the BSE image and corresponding EDS spectral map of sample 05-17. The stark contrast seen between the left and right halves of both images are a result of large sodium chloride grains, interpreted as halite. The EDS spectra of the soil samples were more homogeneous across all samples, reflecting the random mixing involved in their preparation. The $\mathrm{wt} \%$ oxide concentrations (rounded to the nearest percent to reflect the low accuracy of method) in Table 5 were calculated from the normalized mass percentages derived through the quantification procedure. All of the elemental iron present was converted to $\mathrm{wt} \% \mathrm{FeO}$ (see supporting data).

The spectra for some samples gave erroneous results, likely due to the large error associated with the quantification, and only the elements with identifiable peaks were quantified. Two poor quality spectra (4-15 and 8-18) have been omitted in Table 5. 
Table 5. EDS elemental quantification converted to equivalent wt. \% oxides for the different sampling points from the AMADEE-18 mission. Powder sample spectra collected over $\sim 10$ $\mathrm{mm}^{2}$ acquisition areas and normalized.

\begin{tabular}{|c|c|c|c|c|c|c|c|c|c|c|c|c|c|}
\hline & \multicolumn{12}{|c|}{ Samples } & \multirow[b]{2}{*}{$\begin{array}{c}\text { Average } \\
\text { (oxide } \\
\text { wt } \% \text { ) }\end{array}$} \\
\hline $\begin{array}{l}\text { oxide } \\
\text { wt } \%\end{array}$ & $\frac{1}{5}$ & $\frac{\infty}{\frac{1}{8}}$ & $\frac{\infty}{0}$ & $\stackrel{\infty}{\stackrel{1}{I}}$ & 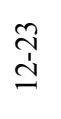 & $\frac{m}{\dot{I}}$ & 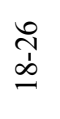 & $\begin{array}{l}\stackrel{2}{ } \\
\text { I }\end{array}$ & $\begin{array}{l}\text { ஸे } \\
\text { ஸे }\end{array}$ & $\begin{array}{l}\stackrel{\sim}{1} \\
\stackrel{\sim}{N}\end{array}$ & $\begin{array}{l}\text { ஸे } \\
\text { ते }\end{array}$ & $\begin{array}{l}\text { ஸे } \\
\text { ஸे }\end{array}$ & \\
\hline $\mathrm{SiO}_{2}$ & 24 & 41 & 33 & 16 & 28 & 32 & 27 & 12 & 22 & 31 & 28 & 28 & 27 \\
\hline $\mathrm{Al}_{2} \mathrm{O}_{3}$ & 5 & 9 & 7 & 2 & 5 & 6 & 5 & 3 & 4 & 6 & 5 & 5 & 5 \\
\hline $\mathrm{FeO}$ & 2 & 4 & 3 & 1 & 2 & 3 & 1 & 1 & 2 & 3 & 2 & 2 & 2 \\
\hline $\mathrm{MgO}$ & 3 & 8 & 5 & 2 & 3 & 5 & 3 & 2 & 3 & 5 & 4 & 3 & 4 \\
\hline $\mathrm{CaO}$ & 27 & 13 & 21 & 34 & 27 & 22 & 20 & 28 & 28 & 23 & 18 & 29 & 24 \\
\hline $\mathrm{Na}_{2} \mathrm{O}$ & 1 & 1 & 1 & 0 & 1 & 1 & 1 & 0 & 1 & 0 & 1 & 1 & 1 \\
\hline $\mathrm{K}_{2} \mathrm{O}$ & 1 & 1 & 1 & 1 & 1 & 1 & 1 & 1 & 1 & 2 & 1 & 1 & 1 \\
\hline $\mathrm{CO}_{2}$ & 37 & 23 & 29 & 44 & 33 & 30 & 42 & 53 & 39 & 30 & 41 & 31 & 39 \\
\hline Total & 100 & 100 & 100 & 100 & 100 & 100 & 100 & 100 & 100 & 100 & 100 & 100 & 103 \\
\hline
\end{tabular}
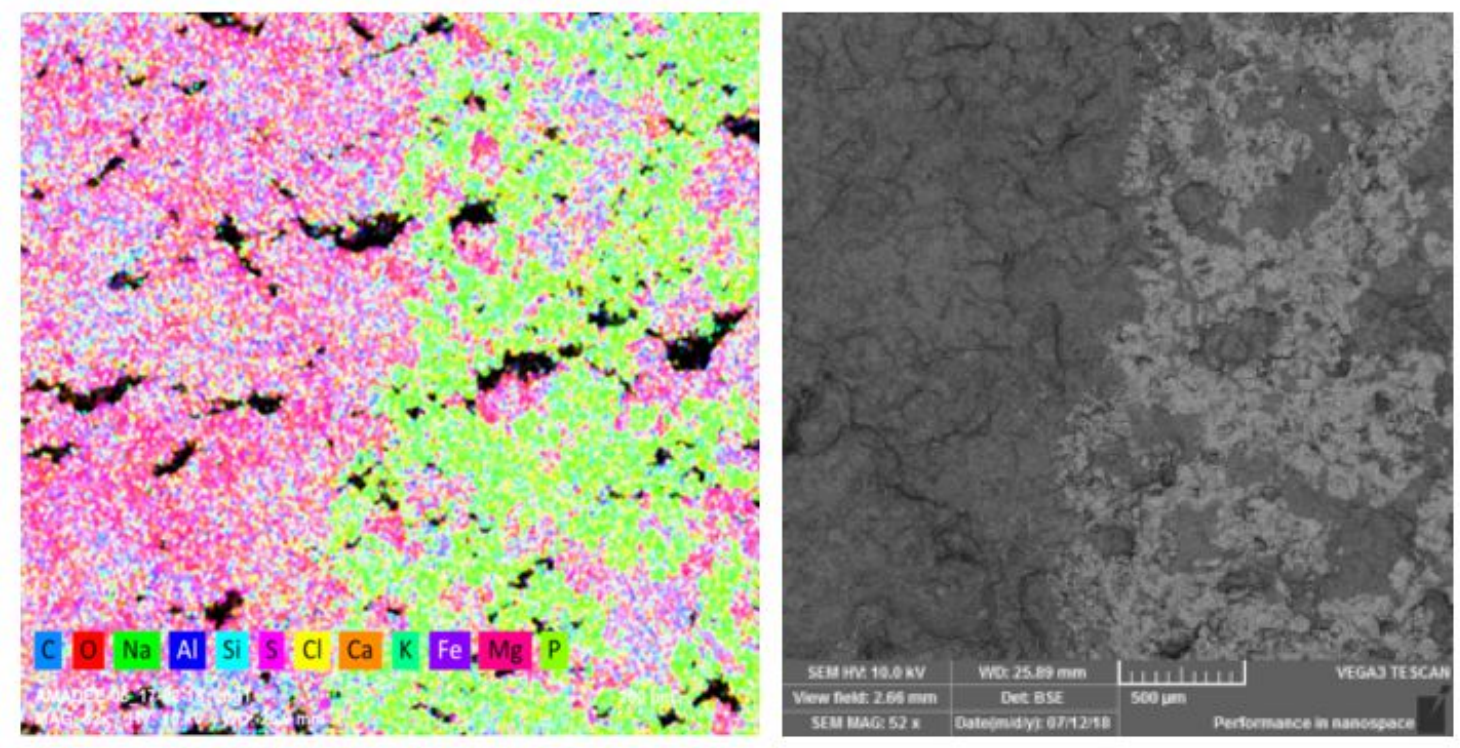

Figure 10. An EDS elemental map of 05-17 (right). The left half of the image is primarily composed of oxygen, silicon, and calcium whereas the right is dominated by sodium and chlorine. BSE image corresponding to area of EDS elemental map (left).

\section{Laser Induced breakdown spectroscopy (LIBS)}

LIBS spectra are shown in Figure 11. The spectral range covers almost all the near-UV, visible, and near-infrared. The main compositional elements are $\mathrm{Al}, \mathrm{Ca}, \mathrm{Ti}, \mathrm{Si}, \mathrm{K}, \mathrm{Fe}$, and $\mathrm{Mg}$, were identified using the NIST Spectral Lines Database (National Institute of Standards and 


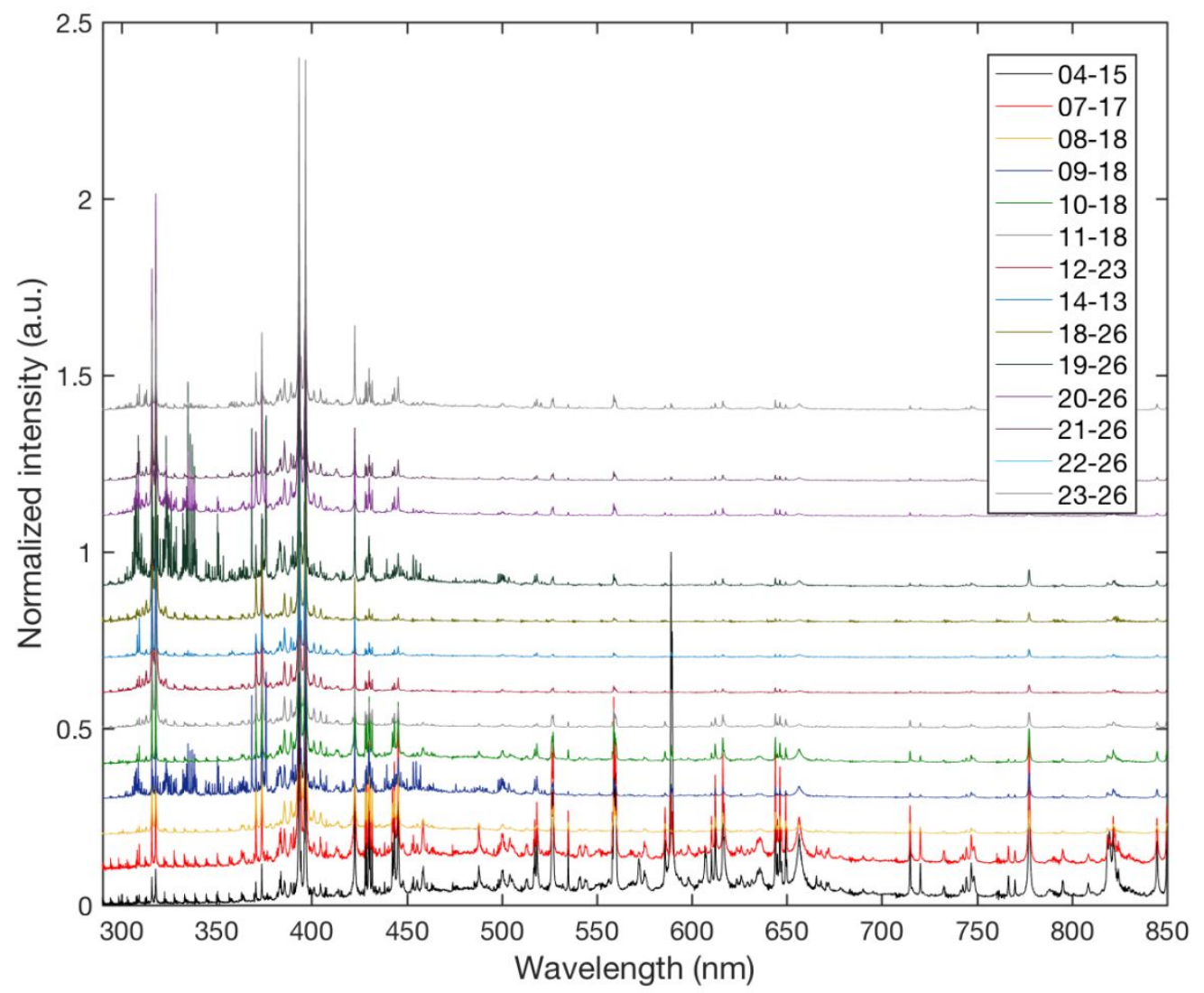

Figure 11. LIBS spectra from the pelletized AMADEE-18 sand samples.

\section{Discussion}

The petrological study of these samples shows evidence of hydrothermal deposits in the Ara Fm previously undescribed. This hydrothermalism is probably related to the syn-rift volcanism in the late stage of formation (Ramseyer et al., 2013; Reuning et al., 2007; Rollinson et al., 2014). It is represented by the existence of the silica veinlets carrying sulfides and oxides intruding the dolomitic rocks studied in the present work. Part of this alteration has generated secondary clays 
being observed in the present samples. Also, a supergene alteration has been observed on the samples reflected by an oxidized coating over the surface of almost all the clasts described. These alterations are supported by the presence of tertiary clays. In general, the supergene alteration was produced by the alluvial water intruding into the outcrops from the surface. The supergene process is combined with other alterations like the weathering and the alteration of the post-rift processes. All of the alteration processes described above are believed to have occurred on Mars. Because of this, this area has being proposed as a key terrestrial Mars analog for alteration processes (Chevrier and Mathé, 2007). The hydrothermalism and supergene alteration observed in the samples are comparable to similar geological data identified by the NASA MSL-Curiosity mission in Mars (Le Deit et al., 2013; Marzo et al., 2010; Popa et al., 2015).

The spectroscopic analyses performed here detected minerals ranging from oxides to complex clays. The detected minerals match those observed using optical microscopy. The detected carbonates like dolomite and calcite correspond to the hydrothermal alteration. The oxides such as hematite and quartz are also significant in the context of understanding the hydrothermal processes. Also, minerals from old volcanism of the region such as pyroxene, feldspar, and olivine were detected. The meteoric alterations have also been detected in the form of clays and the water content on certain samples. The present results also confirm that Raman spectroscopy is able to detect certain mineral species that are not visually differentiable such as olenite, pyrope, or coesite minerals, among others. Also, the results agree with the mineralogy previously reported (Amthor et al., 2005; Ramseyer et al., 2013). The other powerful application of the Raman analysis was the detection of organic materials on the different samples. However, the measurements must be complemented with the capabilities of other laser techniques to get semiquantitative concentrations of the organics present. Given the fast measurements and high sensitivity to target biomolecular structures that are present in the different samples, the best complementary method for detection of organics is LIF. The wavelength range for the detected organics match the range amino-acids like lysine or phenylalanine (Eshelman et al., 2018, 2014). Also, the LIF method helped to confirm the existence of carbonates such as calcite or dolomite and quartz.

The XRD measurements identified and quantified the mineralization present in the different samples. Indeed, the pattern matching facilitated easy identification of quartz, feldspars and carbonates. The detection of some feldspars like albite helped to confirm the hydrothermal alterations. Other minerals (pyroxene and certain feldspars) confirmed the existence of past volcanic activities. The high concentration of carbonates in the analyzed samples was confirmed with LIF, LIBS and EDS. The high concentration of calcite and dolomite agree with the petrological description of the sedimentary rocks. 
The LIBS technique mainly detected $\mathrm{Ca}, \mathrm{Mg}, \mathrm{Al}$ and other metal ions like Fe. These elements could be the cations in the identified carbonates (e.g. dolomite and calcite). However, $\mathrm{Mg}$ and Fe could also be associated with the volcanic parent mineralogy such as pyroxene, olivine or Feoxides (magnetite). This agrees with the Si detected on the samples which could represent the ionization of the pyroxene, olivine, and feldspars. Peaks corresponding to Al can be assigned to the different alkali-feldspar and/or clay mineralization present along all the different sampling points. The $\mathrm{K}$ and Na peaks probably belong to feldspar group minerals because this mineral group presents higher concentrations of $\mathrm{K}$ and $\mathrm{Na}$ compared to other minerals.

The semi-quantitative EDS analysis of the uncoated pellets detected high concentrations of $\mathrm{Si}$, $\mathrm{Ca}$, and $\mathrm{C}$, which is consistent with the dominant mineralogy of calcite, dolomite, and quartz determined through the other experimental techniques applied to the samples. Throughout the laboratory analysis, samples were handled with gloves and stored in sealed containers to minimize contamination. Despite these efforts, it is likely that some of the $\mathrm{C}$ measured by EDS for the samples is due to contamination; however, high concentrations of $\sim 40 \%$ indicate that contamination cannot be the only responsible mechanism, and that the presence of carbonates is probable. Possible contamination factors could include in-situ biological contamination, or sample handling at the Kepler base station during the mission. (Abed et al., 2010) reported that the bacterial community in the region is mainly composed of cyanobacterium (e.g. Deltaproteobacteria, Bacteriodetes, Gemmatimonas and Planctomycetes). However, we have shown that EDS provided a relatively quick and semi-non-destructive mineralogical and geochemical analysis of samples, with elemental results consistent with those derived from the other instruments.

From an astrobiological perspective, carbonates are most commonly associated with potentially habitable zones such as hydrothermal areas, marine or lacustrine sediments, or biominerals (Bish et al., 2013). The carbonates form not only through hydrothermal or diagenetic processes, but they can have an origin of weathering byproducts or from serpentinization. Carbonates provide an energy source for chemosynthetic microbes on Earth. Considering the magnesium-iron rich carbonates detected by the Spirit rover (Morris et al., 2010), the sand studied during the AMADEE-18 mission is a good geological candidate for an in-situ instrument analysis of future space-qualified equipment prototypes and twin systems for future research.

The approach described in this section provides a geo-chemical instrumentation and methodological suite for the comprehensive analysis of a sample, yielding a mineralogical, elemental, organic, petrological, and geomorphological investigation. The results obtained from the different techniques illustrate the applicability of portable systems based on the real flight instruments for future analog missions (E. A. Lalla et al., 2016; Sehlke et al., 2019; Warren- 
Rhodes et al., 2019). Further, the combined measurements of this comprehensive geo-chemical suite in analog space missions will yield insight into how our present methods can be improved upon for future missions to Mars and beyond. Particularly, given the large degree of instrument overlap and complementation, continuous use of the geo-chemical suite in space exploration will facilitate a unique combination in which the instruments ought to be used (Foing et al., 2011; Sehlke et al., 2019; Warren-Rhodes et al., 2019).

Among the possible proposed objectives, the suite of used lab-techniques demonstrated that these analyzes provided us useful information when the "Selection of Instrumentation" comes. It should be noted, that the objective of this work and subsequent conclusions are not in the means by which the samples were collected and archived, nor in how the capability of these specific instruments in the terrestrial analogue compare to potential capabilities on Martian exploration. Rather, we strive to demonstrate how the synthesis of information derived from the aforementioned instruments (whose techniques are highly comparable to those in present and future missions) can be used to maximize mineralogical, petrological and astrobiological inference in a rigorous and efficient way. The information of capabilities from Table 1 combined with the "Data from orbiters and previous missions" could help us to decide an optimized workflow when it is required (see Figure 1). When the traverse plan is included in the workflow, this feature information could help to: (1) determine the logical orders of experiments according to the relevance of the acquired data; (2) duration of the experimental procedure (e.g. how much time and how many astronaut are required, time-lining, among others); and (3) risk assessments from landing site geomorphology, required sensing range, and energy duties (robotic and human).

As we have discussed over the course of the article, there are great mineralogical and astrobiological implications from studying terrestrial analogues, not only from the point of view of instrumentation validation, but also in systematizing methods of inference in the analogue context in addition to the setting of real space exploration. Indeed, data comes at many stages in space exploration; ranging from site selection, standardization of surrounding factors (such as passive reflectance), to the final mineralogical and astrobiological conclusions. Having accepted this, the only feasible way in which the utility of subsequent missions can be optimized is by having the integral processes and methods for inference rigorously established in the terrestrial domain. This is particularly true as we begin to travel with higher frequency beyond Mars.

\section{Conclusion}

1- The different techniques proposed facilitated the petrological, mineralogical and chemistry goals, chemical determination and organic detection for possible habitability within in the framework in Martian research. These analyses are presented to provide guidance for future analog missions like the AMADEE-18 mission. Also, the combined analytical methods will 


\section{Acknowledgement}

We would like to thank The Austrian Space Forum (OWF) and the AMADEE-18 Oman National Steering Committee, in particular Dr. Saleh Al-Shidhani and the government and people of the Sultanate of Oman. The authors are grateful to Dr. K. Tait and V. Di Cecco for the opportunity to carry out measurements at the Royal Ontario Museum (ROM) and their excellent support. Also, the authors want to thank Prof. M. G. Daly for his support and the opportunity to carry out measurements at the Planetary Exploration Instrumentation Laboratory (PIL), York University. E. A. Lalla would like to express gratitude to The Ontario Centre of Excellence (OCE) for the TalentEdge Postdoctoral Funding. Figure 1 and 2 from (Robinet et al., 2013) has been reproduced by permission of Elsevier and proceeded by Copyright Clearance Center's (Order contract 4673711500026) Finally, the authors would like to thank the anonymous reviewers and editor for their helpful and constructive comments and support during the review process that contributed to improving the final version of the paper. 


\section{Supporting Data}

The complete results of the measurements and results presented on the current research manuscript can be found online in the OeWF Multi-Mission Science Data Archive of AMADEE18 Mission at https://mission.oewf.org/archive/

\section{References}

Abed, R.M.M., Al Kharusi, S., Schramm, A., and Robinson, M.D. (2010). Bacterial diversity, pigments and nitrogen fixation of biological desert crusts from the Sultanate of Oman. FEMS Microbiol. Ecol. 72, 418-428. doi:10.1111/j.1574-6941.2010.00854.x

Amthor, J.E., Ramseyer, K., Faulkner, T., and Lucas, P. (2005). Stratigraphy and sedimentology of a chert reservoir at the Precambrian-Cambrian boundary: The Al Shomou Silicilyte, South Oman Salt Basin. GeoArabia 10, 89-122.

Anderson, R., Bridges, J.C., Williams, A., Edgar, L., Ollila, A., Williams, J., Nachon, M., Mangold, N., Fisk, M., Schieber, J., Gupta, S., Dromart, G., Wiens, R., Le Mouélic, S., Forni, O., Lanza, N., Mezzacappa, A., Sautter, V., Blaney, D., Clark, B., Clegg, S., Gasnault, O., Lasue, J., Léveillé, R., Lewin, E., Lewis, K.W., Maurice, S., Newsom, H., Schwenzer, S.P., and Vaniman, D. (2015). ChemCam results from the Shaler outcrop in Gale crater, Mars. Icarus 249, 2-21. doi:10.1016/j.icarus.2014.07.025

Apopei, A.I. and Buzgar, N. (2010). The Raman study of amphiboles. Analele Stiint. ale Univ. “ Al. I. Cuza" din Iasi, Geol. 56, 57-83.

Balachandran, U. and Eror, N.G. (1982). Raman spectra of titanium dioxide. J. Solid State Chem. 42, 276-282. doi:10.1016/0022-4596(82)90006-8

Beegle, L., Bhartia, R., White, M., Deflores, L., Abbey, W., Wu, Y.H., Cameron, B., Moore, J., Fries, M., Burton, A., Edgett, K.S., Ravine, M.A., Hug, W., Reid, R., Nelson, T., Clegg, S., Wiens, R., Asher, and S., Sobron, P. (2015). SHERLOC: Scanning habitable environments with Raman \& luminescence for organics \& chemicals, in: IEEE Aerospace Conference Proceedings. doi:10.1109/AERO.2015.7119105

Bish, D.L., Blake, D.F., Vaniman, D.T., Chipera, S.J., Morris, R. V, Ming, D.W., Treiman, A.H., Sarrazin, P., Morrison, S.M., Downs, R.T., Achilles, C.N., Yen, A.S., Bristow, T.F., Crisp, J.A., Morookian, J.M., Farmer, J.D., Rampe, E.B., Stolper, E.M., Spanovich, N., and Team, M.S.L.S. (2013). X-ray Diffraction Results from Mars Science Laboratory: Mineralogy of Rocknest at Gale Crater. Sci. 341. doi:10.1126/science.1238932 
Black, S.R. and Hynek, B.M. (2018). Characterization of terrestrial hydrothermal alteration products with Mars analog instrumentation: Implications for current and future rover investigations. Icarus 307, 235-259. doi:10.1016/j.icarus.2017.10.032

Bruker-Nano (2011). Introduction to EDS Analysis: Reference Manual, DOC-M82-EX. ed. Bruker Nano GmbH, Berlin, Germany.

Buzgar, N. and Apopei, A.I. (2009). The Raman study on certain carbonates. Analele Stiint. ale Univ. “Al. I. Cuza” - Iasi 55, 97-112.

Chevrier, V. and Mathé, P.E. (2007). Mineralogy and evolution of the surface of Mars: A review. Planet. Space Sci. 55, 289-314. doi:10.1016/j.pss.2006.05.039

Cote, K., Lalla, E., Daly, M. and Tait, K. (2018). Characterization of a Combined Raman, LIF, and LIBS System with Time Resolved Fluorescence Capabilities for Planetary Exploration Applications . Women in Planetary Science and Exploration (WPSE) Conference, Toronto, Canada.

Cremers, D.A. and Radziemski, L.J. (2013). Handbook of Laser-Induced Breakdown Spectroscopy. John Wiley \& Sons Ltd, Oxford, UK. doi:10.1002/9781118567371

Downs, B., Robinson, S., Yang, H. and Mooney, P. (2015). RRUFF Project. Dep. Geosci. Univ. Arizona.

Edwards, H.G.M., Hutchinson, I.B., Ingley, R., Parnell, J., Vítek, P., and Jehlička, J. (2013). Raman Spectroscopic Analysis of Geological and Biogeological Specimens of Relevance to the ExoMars Mission. Astrobiology 13, 543-549. doi:10.1089/ast.2012.0872

Eshelman, E., Daly, M.G., Slater, G., and Cloutis, E. (2018). Detecting aromatic compounds on planetary surfaces using ultraviolet time-resolved fluorescence spectroscopy. Planet. Space Sci. 151, 1-10. doi:10.1016/j.pss.2017.09.003

Eshelman, E., Daly, M.G., Slater, G., and Cloutis, E. (2015). Time-resolved detection of aromatic compounds on planetary surfaces by ultraviolet laser induced fluorescence and Raman spectroscopy. Planet. Space Sci. 119, 200-207. doi:10.1016/j.pss.2015.09.021

Eshelman, E., Daly, M.G., Slater, G., Dietrich, P., and Gravel, J.F. (2014). An ultraviolet Raman wavelength for the in-situ analysis of organic compounds relevant to astrobiology. Planet. Space Sci. 93-94, 65-70. doi:10.1016/j.pss.2014.01.021

Ferrari, A.C. (2007). Raman spectroscopy of graphene and graphite: Disorder, electron-phonon coupling, doping and nonadiabatic effects. Solid State Commun. 143, 47-57. 
Ferraris, G., Dubessy, J., Caumon, M.-C., and Rull, F. (Eds.) (2012). Raman Spectroscopy Applied to Earth Sciences and Cultural Heritage. doi:10.1180/EMU-notes.12

Foing, B.H., Stoker, C., Zavaleta, J., Ehrenfreund, P., Thiel, C., Sarrazin, P., Blake, D., Page, J., Pletser, V., Hendrikse, J., Direito, S., Kotler, J.M., Martins, Z., Orzechowska, G., Gross, C., Wendt, L., Clarke, J., Borst, A.M., Peters, S.T.M., Wilhelm, M.-B., Davies, G.R., and Team, I.E. (2011). Field astrobiology research in Moon-Mars analogue environments: instruments and methods. Int. J. Astrobiol. 10, 141-160. doi:10.1017/S1473550411000036

Freeman, J.J., Wang, A., Kuebler, K.E., Jolliff, B.L., and Haskin, L.A. (2008). Characterization of natural feldspars by raman spectroscopy for future planetary exploration. Can. Mineral. 46, 1477-1500. doi:10.3749/canmin.46.6.1477

Garnitschnig, S. (Oewf) (2018). Development of a supportive method for the detection of biomarkers during future-robotic Mars missions. University of Inssbruck and Space Austrian forum.

Groemer, G., (2018). AMADE-188 Mission Report. Inssbruck. doi:https://oewf.org/en/portfolio/amadee-18

Groemer, G., Gruber, S., Uebermasser, S., Soucek, A., Lalla, E., Lousada, J., Sams, S., Sejkora, N., Garnitschnig, S., and Sattler, B. (2019). The AMADEE-18 Mars Analog Expedition in the Dhofar region of Oman. Astrobiology in press.

Gruber, S., Groemer, G., and Haider, O. (2019). Inspiring the next generation through the AMADEE-18 MARS analog simulation. Acta Astronaut. 164, 204-211. doi:10.1016/J.ACTAASTRO.2019.08.008

Huang, E., Chen, C.H., Huang, T., Lin, E.H., and Xu, J.A. (2000). Raman spectroscopic characteristics of Mg-Fe-Ca pyroxenes. Am. Mineral. 85, 473-479.

Klein, C. (2008). Minerals and rocks : exercises in crystal and mineral chemistry, crystallography, X-ray powder diffraction, mineral and rock identification, and ore mineralogy. Wiley.

Konstantinidis, M., Cote, K., Lalla, E.A., Zhang, G., Daly, M.G., Gao, X., and Dietrich, P. (2019). On the application of a novel linear mixture model on laser-induced breakdown spectroscopy: Implications for Mars. J. Chemom. e3174. doi:10.1002/cem.3174

Laetsch, T. and Downs, R. (2006). Software For Identification and Refinement of Cell Parameters From Powder Diffraction Data of Minerals Using the RRUFF Project and 
American Mineralogist Crystal Structure Databases. Kobe, Japan.

Lalla, E., López-Reyes, G., Sansano, A., Sanz-Arranz, A., Schmanke, D., Klingelhöfer, G., Medina-García, J., Martínez-Frías, J., and Rull-Pérez, F. (2015). Estudio espectroscópico y DRX de afloramientos terrestres volcánicos en la isla de Tenerife como posibles análogos de la geología marciana. Estud. Geológicos 71, 1-19. doi:10.3989/egeol.41927.354

Lalla, E., Sanz-Arranz, A., Lopez-Reyes, G., Cote, K., Daly, M., Konstantinidis, M., RodriguezLosada, J.A., Groemer, G., Medina, J., Martínez-Frías, J., and Rull-Pérez, F. (2019). A micro-Raman and X-ray study of erupted submarine pyroclasts from El Hierro (Spain) and its' astrobiological implications. Life Sci. Sp. Res. 21, 49-64. doi:10.1016/J.LSSR.2019.04.003

Lalla, E.A., Sanz-Arranz, A., Lopez-Reyes, G., Sansano, A., Medina, J., Schmanke, D., Klingelhoefer, G., Rodríguez-Losada, J.A., Martínez-Frías, J., and Rull, F. (2016). Raman-Mössbauer-XRD studies of selected samples from "Los Azulejos" outcrop: A possible analogue for assessing the alteration processes on Mars. Adv. Sp. Res. 57, 23852395. doi:10.1016/j.asr.2016.03.014

Le Deit, L., Mangold, N., Forni, O., Cousin, A., Lasue, J., Schröder, S., Wiens, R.C., Sumner, D., Fabre, C., Stack, K.M., Anderson, R.B., Blaney, D., Clegg, S., Dromart, G., Fisk, M., Gasnault, O., Grotzinger, J.P., Gupta, S., Lanza, N., Le Mouélic, S., Maurice, S., McLennan, S.M., Meslin, P.-Y., Nachon, M., Newsom, H., Payré, V., Rapin, W., Rice, M., Sautter, V., and Treiman, A.H. (2013). The potassic sedimentary rocks in Gale Crater, Mars, as seen by ChemCam on board Curiosity. J. Geophys. Res. Planets 121, 784-804. doi:10.1002/2015JE004987

Lepvrier, C., Fournier, M., Bérard, T., and Roger, J. (2002). Cenozoic extension in coastal Dhofar (southern Oman): Implications on the oblique rifting of the Gulf of Aden. Tectonophysics 357, 279-293. doi:10.1016/S0040-1951(02)00372-4

Léveillé, R. (2009). Validation of astrobiology technologies and instrument operations in terrestrial analogue environments. Comptes Rendus Palevol 8, 637-648. doi:http://dx.doi.org/10.1016/j.crpv.2009.03.005

Lymer, E.A. (2018). Laser-Induced Fluorescence Spectroscopy as a Non-Destructive Technique for Mineral and Organic Detection in Carbonaceous Chondrites. York University, MSc Thesis.

Markovski, C., Byrne, J.M., Lalla, E., Lozano-Gorrín, A.D., Klingelhöfer, G., Rull, F., Kappler, A., Hoffmann, T., and Schröder, C. (2017). Abiotic versus biotic iron mineral 
transformation studied by a miniaturized backscattering Mössbauer spectrometer (MIMOS II), X-ray diffraction and Raman spectroscopy. Icarus 296, 49-58. doi:https://doi.org/10.1016/j.icarus.2017.05.017

Martin, J.D. (2004). Using XPowder: a software package for powder X-ray diffraction analysis. Granada Spain.

Marzo, G.A., Davila, A.F., Tornabene, L.L., Dohm, J.M., Fairén, A.G., Gross, C., Kneissl, T., Bishop, J.L., Roush, T.L., and McKay, C.P. (2010). Evidence for Hesperian impactinduced hydrothermalism on Mars. Icarus 208, 667-683. doi:10.1016/J.ICARUS.2010.03.013

Michalski, J.R., Dobrea, E.Z.N.N., Niles, P.B., and Cuadros, J. (2017). Ancient hydrothermal seafloor deposits in Eridania basin on Mars. Nat. Commun. 8, 15978. doi:10.1038/ncomms 15978

Morris, R. V, Ruff, S.W., Gellert, R., Ming, D.W., Arvidson, R.E., Clark, B.C., Golden, D.C., Siebach, K., Klingelhöfer, G., Schröder, C., Fleischer, I., Yen, A.S., and Squyres, S.W. (2010). Identification of Carbonate-Rich Outcrops on Mars by the Spirit Rover. Sci. 329, 421-424. doi:10.1126/science.1189667

National Institute of Standards and Technology (2016). LIBS Spectral bands NIST - Database. URL http://www.nist.gov/pml/data/asd.cfm

Palache, C., Berman, H., and Frondel, C. (1952). Dana's System of Mineralogy. 7. Ed. Geol. Föreningen i Stock. Förhandlingar 74, 218-219. doi:10.1080/11035895209453366

Popa, C., Carrozzo, F.G., Di Achill, G., Silvestro, S., Esposito, F., and Mennella, V. (2015). First Supergene Enrichment Zone Discovered in Shalbatana Valley: Constrains on Martian Early Atmosphere. pp. 4-5. doi:10.1029/2005JE004234.Figure

Ramseyer, K., Amthor, J.E., Matter, A., Pettke, T., Wille, M., and Fallick, A.E. (2013). Primary silica precipitate at the Precambrian/Cambrian boundary in the South Oman Salt Basin, Sultanate of Oman. Mar. Pet. Geol. 39, 187-197. doi:10.1016/j.marpetgeo.2012.08.006

Reuning, L., Schoenherr, J., Heiman, A., Kukl, P.A., Urai, J.L., and Littke, R. (2007). The salt domes of the Ghaba Salt Basin: An analogue for the hydrocarbon plays of the South Oman Salt Basin . Preliminary Evolutionary Model Facies model SOSB : Facies salt domes : 6 . Maturity : Solid Bitumen References : 2007. doi:10.1016/j.orggeochem.2007.03.010.Thrombolites 
Robinet, J., Razin, P., Serra-Kiel, J., Gallardo-Garcia, A., Leroy, S., Roger, J., and Grelaud, C., (2013). The Paleogene pre-rift to syn-rift succession in the Dhofar margin (northeastern Gulf of Aden): Stratigraphy and depositional environments. Tectonophysics 607, 1-16. doi:10.1016/J.TECTO.2013.04.017

Roger, J., Platel, J.P., Cavelier, C., and Bourdillon-de-Grissac, C. (1989). Donnees nouvelles sur la stratigraphie et l'histoire geologique du Dhofar (sultanat d'Oman). Bull. la Société Géologique Fr. V, 265-277. doi:10.2113/gssgfbull.v.2.265

Rollinson, H.R., Searle, M.P., Abbasi, I.A., Al-Lazki, A.I., and Al Kindi, M.H. (2014). Tectonic evolution of the Oman Mountains: an introduction. Geol. Soc. London, Spec. Publ. 392, 1-7. doi:10.1144/SP392.1

Rull-Perez F. and Martinez-Frias, J. (2003). Identification of calcite grains in the Vaca Muerta mesosiderite by Raman spectroscopy. J. Raman Spectrosc. 34, 367-370. doi:10.1002/jrs. 1003

Rull, F., Maurice, S., Hutchinson, I., Moral, A., Perez, C., Diaz, C., Colombo, M., Belenguer, T., Lopez-Reyes, G., Sansano, A., Forni, O., Parot, Y., Striebig, N., Woodward, S., Howe, C., Tarcea, N., Rodriguez, P., Seoane, L., Santiago, A., Rodriguez-Prieto, J.A., Medina, J., Gallego, P., Canchal, R., Santamaría, P., Ramos, G., and Vago, J.L., on behalf of the RLS Team (2017). The Raman Laser Spectrometer for the ExoMars Rover Mission to Mars. Astrobiology. doi:10.1089/ast.2016.1567

Sehlke, A., Mirmalek, Z., Burtt, D., Haberle, C.W., Santiago-Materese, D., Kobs Nawotniak, S.E., Hughes, S.S., Garry, W.B., Bramall, N., Brown, A.J., Heldmann, J.L., and Lim, D.S.S. (2019). Requirements for Portable Instrument Suites during Human Scientific Exploration of Mars. Astrobiology 19, 401-425. doi:10.1089/ast.2018.1841

Sejkora, N., Sams, S., and Groemer, G. (2018). Geodata workflow for the AMADEE-18 Mars analog mission, in: European Planetary Science Congress 2018. p. Vol (12), 442.

Storrie-Lombardi, M.C., Muller, J.-P., Fisk, M.R., Cousins, C., Sattler, B., Griffiths, A.D., and Coates, A.J. (2009). Laser-Induced Fluorescence Emission (L.I.F.E.): Searching for Mars Organics with a UV-Enhanced PanCam. Astrobiology 9, 953-964. doi:10.1089/ast.2009.0353

Stromberg, J.M., Parkinson, A., Morison, M., Cloutis, E., Casson, N., Applin, D., Poitras, J., Marti, A.M., Maggiori, C., Cousins, C., Whyte, L., Kruzelecky, R., Das, D., Leveille, R., Berlo, K., Sharma, S.K., Acosta-Maeda, T., Daly, M., and Lalla, E. (2019). Biosignature detection by Mars rover equivalent instruments in samples from the CanMars Mars 
Sample Return Analogue Deployment. Planet. Space Sci. doi:10.1016/J.PSS.2019.06.007

Wang, A., Jolliff, B.L., Haskin, L.A., Kuebler, K.E., and Viskupic, K.M. (2001).

Characterization and comparison of structural and compositional features of planetary quadrilateral pyroxenes by Raman spectroscopy. Am. Mineral. 86, 790-806.

Wang, A., Kuebler, K.E., Jolliff, B.L., and Haskin, L.A. (2004). Raman spectroscopy of Fe-TiCr-oxides, case study: Martian meteorite EETA79001. Am. Mineral. 89, 665 LP - 680.

Warren-Rhodes, K.A., Lee, K.C., Archer, S.D.J., Cabrol, N., Ng-Boyle, L., Wettergreen, D., Zacny, K., and Pointing, S.B. (2019). Subsurface Microbial Habitats in an Extreme Desert Mars-Analog Environment . Front. Microbiol 10, 69. DOI: 10.3389/fmicb.2019.00069.

Wiens, R.C., Maurice, S., Barraclough, B., Saccoccio, M., Barkley, W.C., Bell, J.F., Bender, S., Bernardin, J., Blaney, D., Blank, J., Bouyé, M., Bridges, N., Bultman, N., Caïs, P., Clanton, R.C., Clark, B., Clegg, S., Cousin, A., Cremers, D., Cros, A., DeFlores, L., Delapp, D., Dingler, R., D’Uston, C., Darby Dyar, M., Elliott, T., Enemark, D., Fabre, C., Flores, M., Forni, O., Gasnault, O., Hale, T., Hays, C., Herkenhoff, K., Kan, E., Kirkland, L., Kouach, D., Landis, D., Langevin, Y., Lanza, N., LaRocca, F., Lasue, J., Latino, J., Limonadi, D., Lindensmith, C., Little, C., Mangold, N., Manhes, G., Mauchien, P., McKay, C., Miller, E., Mooney, J., Morris, R. V, Morrison, L., Nelson, T., Newsom, H., Ollila, A., Ott, M., Pares, L., Perez, R., Poitrasson, F., Provost, C., Reiter, J.W., Roberts, T., Romero, F., Sautter, V., Salazar, S., Simmonds, J.J., Stiglich, R., Storms, S., Striebig, N., Thocaven, J.-J., Trujillo, T., Ulibarri, M., Vaniman, D., Warner, N., Waterbury, R., Whitaker, R., Witt, J., and Wong-Swanson, B. (2012). The ChemCam Instrument Suite on the Mars Science Laboratory (MSL) Rover: Body Unit and Combined System Tests. Space Sci. Rev. 170, 167-227. doi:10.1007/s11214-012-9902-4

Wiens, R.C., Maurice, S., Mccabe, K., Cais, P., Anderson, R.B., Beyssac, O., Bonal, L., Clegg, S., Deflores, L., Dromart, G., Wiens, R.C., Maurice, S., Mccabe, K., Cais, P., Anderson, R.B., and Supercam Team (2016). The SuperCam Remote Sensing Instrument Suite for Mars 2020 To cite this version : HAL Id : insu-01285184.

Yuan, Y., Kusky, T.M., and Rajendran, S. (2016). Tertiary and quaternary marine terraces and planation surfaces of northern Oman: Interaction of flexural bulge migration associated with the Arabian-Eurasian collision and eustatic sea level changes. J. Earth Sci. 27, $955-$ 970. doi:10.1007/s12583-015-0656-2 


\section{List of Figures}

Figure. 1. Simplified geological map of southern Oman (Dhofar area) showing the two studied areas discussed in this paper from (Robinet et al., 2013). (Reproduced by permission of Elsevier).

Figure. 2. The Paleocene-Miocene stratigraphic units of the Dhofar region from (Robinet et al., 2013). (Reproduced by permission of Elsevier).

Figure 3. Picture of field site showing the outcrops and alluvial fans deposits from were samples were taking and study in laboratory.

Figure 4. (a) Analog astronauts doing a geo-sampling in the field during the AMADEE-18 mission, (b) Digital Model Elevation (DEM) map of the sampling points with the location, and Digital Elevation Map (DEM) (the coordinates of sampling location are on the supporting material), (c) example of one the geo-samples cataloged at York University, and (d) pelletized sand samples.

Figure 5. Magnified images of the alluvial fan sediments and sand to gravel size material. (a) Dolomites, silicate, carbonate clasts with feldspar crystals; (b) sand with presence of volcanic quartz, feldspar, disseminated oxides and gravel size clast; (c) rounded volcanic quartz, dolomite clasts, rounded basalt clast and alunite and feldspar crystals; (d) andesite sub-rounded clast with abundant presence of volcanic quartz, and oxides and disseminated alunite crystals; (e) amphibole in fine grained silica with chloritized mineralization in center and oxides in borders. Abbreviations: Fsp (feldspar), V Qtz (volcanic quartz), Alu (alunite) and Ox (oxide).

Figure 6. Magnified images of the alteration processes. (a) The silicate replacing dolomite rock from Ara Fm with oxide coating on the surface; (b) silica vein intruded in Ara Fm carrying magnetite and sulfides; (c) silicate replacing carbonate rocks from Ara Fm (possible evidence of supergen activity); (d) random dissemination of oxides and alunite crystals in silica vein matrix; (d) fine to very fine silica matrix replacing carbonate rocks (details of carbonate clast and silica veins in process of replacement can be observed). Abbreviations: dolomite (Dol), magnetite (Mag), and alunite (Alu).

Figure 7. Micro-Raman spectra of the most significant mineral phases detected.

Figure 8. X-Ray diffractogram of the selected transect points from the AMADEE-18 Mission. The minerals shown are the higher concentration obtained from the quantification (see supporting materials). Abbreviations: quartz (Qtz), calcite (Cal) and feldspar (Fsp).

Figure 9. Representative LIF measurements (20 points along a $1 \mathrm{~cm}$ line) from the different sampling points from AMADEE-18: (a) 09-18; (b) 10-18; (c) 12-23; (d) 18-26; (e) selected spectral comparison with some organics and minerals 
Figure 10. An EDS elemental map of 05-17 (right). The left half of the image is primarily composed of oxygen, silicon, and calcium whereas the right is dominated by sodium and chlorine. BSE image corresponding to area of EDS elemental map (left).

Figure 11. LIBS spectra from the pelletized AMADEE-18 sand samples. 


\section{List of Tables}

Table 1. Comparison of the capabilities of the 5 systems employed in this investigation. (RLS=Raman Laser Spectrometer), (ChemCam=Chemistry and Camera), (Sherloc $=$ Scanning Habitable Environments with Raman \& Luminescence for Organics \& Chemicals), (CheMin= Chemistry and Mineralogy), (MSL=Mars Science Laboratory)

\begin{tabular}{|c|c|c|c|c|c|c|}
\hline $\begin{array}{l}\text { Laboratory } \\
\text { Technique }\end{array}$ & $\begin{array}{c}\text { Mineral } \\
\text { Identification }\end{array}$ & $\begin{array}{c}\text { Elemental } \\
\text { Composition }\end{array}$ & $\begin{array}{l}\text { Organic } \\
\text { detection }\end{array}$ & $\begin{array}{c}\text { Geological } \\
\text { Context }\end{array}$ & $\begin{array}{c}\text { Laboratory } \\
\text { instrumentation } \\
\text { location in this study }\end{array}$ & $\begin{array}{c}\text { Rover } \\
\text { Instrument } \\
\text { Equivalent }\end{array}$ \\
\hline $\begin{array}{c}\text { Raman } \\
\text { Spectroscopy }\end{array}$ & Yes & $\begin{array}{l}\text { Potentially } \\
\text { (only major } \\
\text { elements) }\end{array}$ & Yes & $\begin{array}{c}\text { Yes } \\
\text { (mapping) }\end{array}$ & Royal Ontario Museum & $\begin{array}{l}\text { RLS (ExoMars) } \\
\text { SuperCam } \\
\text { (Mars 2020) } \\
\text { Sherloc } \\
\text { (Mars2020) }\end{array}$ \\
\hline $\begin{array}{l}\text { Micro- } \\
\text { imaging }\end{array}$ & Yes & No & Yes & Yes & York University & $\begin{array}{c}\text { CLUPI } \\
\text { (ExoMars) }\end{array}$ \\
\hline XRD & Yes & No & No & Potentially & Royal Ontario Museum & CheMin (MSL) \\
\hline LIBS & No & Yes & Potentially & $\begin{array}{c}\text { Yes } \\
\text { (mapping) }\end{array}$ & York University & $\begin{array}{c}\text { ChemCam } \\
\text { (MSL) } \\
\text { SuperCam } \\
\text { (Mars 2020) }\end{array}$ \\
\hline LIF & Potentially & No & Yes & No & York University & $\begin{array}{c}\text { Sherloc (Mars } \\
\text { 2020) }\end{array}$ \\
\hline SEM-EDX & $\begin{array}{c}\text { Yes } \\
\text { (Imaging) }\end{array}$ & $\begin{array}{c}\text { Yes } \\
\text { (Qualitative) }\end{array}$ & Yes & No & York University & \\
\hline
\end{tabular}


Table 2. Micro-Raman mineral and other material detection on the different sampling points from AMADEE-18 Mission. $\mathrm{X}$ indicates that the mineral was found to be present in the respective sample.

\begin{tabular}{|c|c|c|c|c|c|c|c|c|c|c|c|c|c|c|c|}
\hline & \multicolumn{15}{|c|}{ Samples } \\
\hline Mineral & $\frac{n}{d}$ & $\frac{1}{2}$ & $\frac{1}{5}$ & $\frac{\infty}{1}$ & $\frac{\infty}{\frac{1}{8}}$ & $\frac{\infty}{1}$ & $\stackrel{\infty}{=}$ & 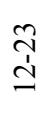 & $\frac{m}{\dot{I}}$ & $\begin{array}{l}\stackrel{1}{1} \\
\infty \\
0\end{array}$ & $\begin{array}{l}\text { त̄ } \\
\stackrel{2}{2}\end{array}$ & $\begin{array}{l}\text { İ } \\
\text { İ }\end{array}$ & $\stackrel{\stackrel{\sim}{N}}{\stackrel{N}{N}}$ & $\begin{array}{l}\text { İ } \\
\text { ते }\end{array}$ & $\begin{array}{l}\text { ָे } \\
\text { ते }\end{array}$ \\
\hline Magnetite & $X$ & $X$ & 8 & & & $\mathrm{X}$ & & $X$ & & $\mathrm{X}$ & & & $X$ & $X$ & $\mathrm{X}$ \\
\hline Hematite & & & 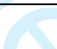 & & & $\mathrm{X}$ & & $X$ & $X$ & $\mathrm{X}$ & $X$ & & & $X$ & $\mathrm{X}$ \\
\hline Goethite & & & $\Delta$ & 8 & & $X$ & & & & & & & & & \\
\hline Anatase & & $X$ & & 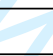 & & & $X$ & & & & $X$ & $X$ & & $X$ & \\
\hline Chromite & & & & 8 & & & & & & & & $X$ & & & \\
\hline Quartz & $\mathrm{X}$ & $X$ & $\mathrm{X}$ & $X$ & $\mathrm{X}$ & $\mathrm{X}$ & $\mathrm{X}$ & $\mathrm{X}$ & $X$ & $\mathrm{X}$ & $X$ & $X$ & $\mathrm{X}$ & $X$ & $\mathrm{X}$ \\
\hline Calcite & $X$ & $X$ & $X$ & $X$ & $X$ & $X$ & $X$ & $X$ & $X$ & $X$ & $X$ & $X$ & $X$ & $X$ & $X$ \\
\hline Dolomite & & $X$ & & & & 8 & & $X$ & & & & & $\mathrm{X}$ & & \\
\hline Titanite & & & & & & $\mathrm{X}$ & 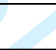 & & & & & & & & \\
\hline Olenite & & & & & & - & 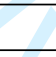 & & & & & $X$ & & & \\
\hline Enstatite & & $\mathrm{X}$ & & & & 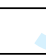 & L & 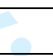 & & & $X$ & & & & \\
\hline Diopside & & & & & & & $X$ & & 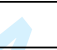 & & $\mathrm{X}$ & & & & \\
\hline Epidote & & & & & & & & 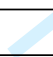 & 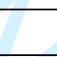 & & & & $X$ & & $X$ \\
\hline Microcline & & & & $X$ & & & & $X$ & 8 & & & & & $X$ & \\
\hline Orthoclase & & & & & & & & & $P$ & & & & $\mathrm{X}$ & & \\
\hline Sanidine & & & & $X$ & $\mathrm{X}$ & $\mathrm{X}$ & $\mathrm{X}$ & & tr & & & $X$ & & & \\
\hline Albite & & $\mathrm{X}$ & & & $X$ & $X$ & & $X$ & $X$ & & $X$ & $X$ & $\mathrm{X}$ & & $X$ \\
\hline Andesine & & & & & $\mathrm{X}$ & & & $X$ & & & $X$ & & & & \\
\hline Labradorite & $X$ & & & & & & & & & & 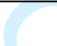 & & & & $X$ \\
\hline Clays & & & & & & $\mathrm{X}$ & & & & & 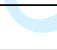 & e & & & \\
\hline $\begin{array}{c}\text { Carbonaceous } \\
\text { Material and } \\
\text { organics }\end{array}$ & $\mathrm{X}$ & $\mathrm{X}$ & $\mathrm{X}$ & $\mathrm{X}$ & $\mathrm{X}$ & $\mathrm{X}$ & $\mathrm{X}$ & $\mathrm{X}$ & $\mathrm{X}$ & $\mathrm{X}$ & $\mathrm{X}$ & $\bar{X}$ & $\mathrm{X}$ & $\mathrm{X}$ & $\mathrm{X}$ \\
\hline
\end{tabular}


Table 3. XRD mineral detection on the different sampling points from AMADEE-18 Mission. $\mathrm{X}$ corresponds to the detected mineral in each collected sample.

\begin{tabular}{|c|c|c|c|c|c|c|c|c|c|c|c|c|c|c|}
\hline 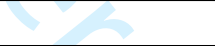 & \multicolumn{14}{|c|}{ Samples } \\
\hline & $\frac{n}{d}$ & $\frac{1}{\frac{1}{0}}$ & $\stackrel{\infty}{1}$ & $\frac{\infty}{\frac{1}{\sigma}}$ & $\frac{\infty}{b}$ & $\stackrel{\infty}{\stackrel{1}{二}}$ & $\begin{array}{l}\stackrel{\sim}{\sim} \\
\stackrel{1}{d}\end{array}$ & $\frac{m}{\dot{J}}$ & $\begin{array}{l}\underset{1}{\alpha} \\
\infty \\
\infty\end{array}$ & $\begin{array}{l}\stackrel{2}{1} \\
\text { á }\end{array}$ & $\begin{array}{l}\stackrel{0}{N} \\
\stackrel{d}{\nu}\end{array}$ & $\frac{⿱}{1}$ & 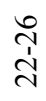 & $\begin{array}{l}\text { ָे } \\
\stackrel{\sim}{\sim}\end{array}$ \\
\hline Iron-Oxides & $\bar{s}$ & & & & $X$ & & & & & & & & & \\
\hline Anatase & $\mathrm{X}$ & 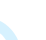 & & & & & & & & & & & $\mathrm{X}$ & \\
\hline Rutile & $\mathrm{X}$ & 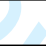 & & & & & & & & & & & $\mathrm{X}$ & \\
\hline Quartz & & $\mathrm{X}$ & $\mathrm{X}$ & X & X & $\mathrm{X}$ & X & & $\mathrm{X}$ & $\mathrm{X}$ & $\mathrm{X}$ & $X$ & $\mathrm{X}$ & X \\
\hline Calcite & & $\mathrm{X}$ & $\mathrm{X}$ & $\mathrm{X}$ & $\mathrm{X}$ & $\mathrm{X}$ & $\mathrm{X}$ & $\mathrm{X}$ & $\mathrm{X}$ & $\mathrm{X}$ & $\mathrm{X}$ & $\mathrm{X}$ & $\mathrm{X}$ & $\mathrm{X}$ \\
\hline Dolomite & & $\mathrm{X}$ & $\mathrm{X}$ & $\mathrm{X}$ & & $\mathrm{X}$ & & & & $\mathrm{X}$ & & & & \\
\hline Ferrosilite & & & & & & & & $\mathrm{X}$ & & & & $\mathrm{X}$ & & \\
\hline Olenite & & & The & 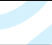 & & & & & & & $\mathrm{X}$ & & & \\
\hline Diopside & $\mathrm{X}$ & & & $P$ & 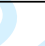 & & & & & & & & & \\
\hline Pigeonite & & & & 8 & 8 & & X & & & & & & & \\
\hline Enstatite & & & $\mathrm{X}$ & & 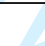 & 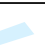 & & $\mathrm{X}$ & & & & & & \\
\hline Epidote & & & & & & ( & 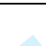 & & & & & & & $\mathrm{X}$ \\
\hline Pyrope & & & $\mathrm{X}$ & & & - & 1 & & & & $\mathrm{X}$ & & & \\
\hline Coesite & & & & & & $\bar{P}$ & $\mathrm{X}$ & & & & & & & \\
\hline Olivine & & & & & & $X$ & 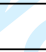 & 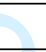 & $\mathrm{X}$ & & & & & \\
\hline Feldspar & & & & & & & 7 & + & $\mathrm{X}$ & & & & & $\mathrm{X}$ \\
\hline Anorthoclase & & & & & & & & 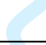 & & & & & $\mathrm{X}$ & \\
\hline Orthoclase & & & & $\mathrm{X}$ & & & & & 8 & $\nabla$ & & & & \\
\hline Sanidine & & & & & & & $\mathrm{X}$ & & $C$ & $\mathrm{~A}$ & & & & \\
\hline Anorthite & & & & & $\mathrm{X}$ & & & & 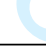 & $\mathrm{X}$ & & & & \\
\hline Albite & $\mathrm{X}$ & & $\mathrm{X}$ & $\mathrm{X}$ & & & & $\mathrm{X}$ & & 8 & & $\mathrm{X}$ & & \\
\hline Bytownite & & & & & & & & & & & $\mathrm{X}$ & & & \\
\hline Andesine & X & $\mathrm{X}$ & & & & & & & & & & 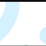 & & \\
\hline Labradorite & $\mathrm{X}$ & & & & & & & $\mathrm{X}$ & & & & 8 & & \\
\hline
\end{tabular}


Table 4. Main LIF minealogical detection for the different sampling points from AMADEE-18 Mission (20-point mapping of $1 \mathrm{~cm}$ line). (** The carbonate and organic signatures were considered only for more than $15 \%$ of detection - more than 3 points

\begin{tabular}{|c|c|c|c|c|c|c|c|c|c|c|c|c|c|c|}
\hline 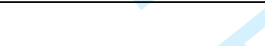 & \multicolumn{14}{|c|}{ Samples } \\
\hline & $\frac{n}{d}$ & $\frac{1}{1}$ & $\frac{\infty}{1}$ & $\frac{\infty}{1}$ & $\frac{\infty}{0}$ & $\stackrel{\infty}{ \pm}$ & $\begin{array}{l}\tilde{c} \\
\stackrel{\sim}{\simeq}\end{array}$ & $\frac{2}{\dot{I}}$ & $\begin{array}{l}\stackrel{\sim}{\sim} \\
\infty \\
\infty\end{array}$ & \begin{tabular}{l} 
đ̃ \\
\multicolumn{2}{c}{}
\end{tabular} & $\begin{array}{l}\text { iे } \\
\text { ஸे }\end{array}$ & $\frac{\text { ì }}{\stackrel{N}{N}}$ & \begin{tabular}{l} 
İ \\
\multirow{1}{N}{}
\end{tabular} & $\begin{array}{l}\text { ते } \\
\text { ते }\end{array}$ \\
\hline $\begin{array}{l}\text { Silicate (Quartz, } \\
\text { Amorphous sand) }\end{array}$ & $\mathrm{X}$ & $\mathrm{X}$ & $\mathrm{X}$ & $\mathrm{X}$ & $\mathrm{X}$ & $\mathrm{X}$ & $\mathrm{X}$ & $\mathrm{X}$ & $\mathrm{X}$ & $\mathrm{X}$ & $\mathrm{X}$ & $\mathrm{X}$ & $\mathrm{X}$ & $\mathrm{X}$ \\
\hline $\begin{array}{l}\text { Carbonates (Calcite } \\
\text { or dolomite) }\end{array}$ & $\mathrm{X}$ & $\mathrm{X}$ & $\mathrm{X}$ & & & & & $\mathrm{X}$ & $\mathrm{X}$ & $\mathrm{X}$ & $\mathrm{X}$ & $\mathrm{X}$ & $\mathrm{X}$ & \\
\hline Organic signature** & $\mathrm{X}$ & $\mathrm{X}$ & 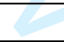 & $\mathrm{X}$ & $\mathrm{X}$ & $\mathrm{X}$ & $\mathrm{X}$ & $\mathrm{X}$ & & & $\mathrm{X}$ & 5 & $\mathrm{X}$ & $\mathrm{X}$ \\
\hline
\end{tabular}

Table 5. EDS elemental quantification converted to equivalent wt. \% oxides for the different sampling points from the AMADEE-18 mission. Powder sample spectra collected over $\sim 10 \mathrm{~mm}^{2}$ acquisition areas, and normalized.

\begin{tabular}{|c|c|c|c|c|c|c|c|c|c|c|c|c|c|}
\hline & \multicolumn{12}{|c|}{ Samples } & \multirow[b]{2}{*}{$\begin{array}{c}\text { Average } \\
\text { (oxide } \\
\text { wt } \% \text { ) }\end{array}$} \\
\hline $\begin{array}{l}\text { oxide } \\
\text { wt } \%\end{array}$ & $\frac{1}{\hat{0}}$ & $\frac{\infty}{8}$ & $\frac{\infty}{1}$ & $\stackrel{\infty}{\stackrel{1}{\leftrightarrows}}$ & 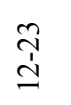 & $\frac{m}{d}$ & 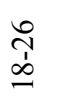 & $\begin{array}{l}\stackrel{2}{1} \\
\stackrel{1}{\sigma}\end{array}$ & $\begin{array}{l}\text { İ } \\
\text { ஸे }\end{array}$ & 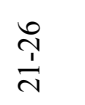 & $\begin{array}{l}\text { İ } \\
\stackrel{\sim}{N}\end{array}$ & $\begin{array}{l}\text { N1 } \\
\stackrel{\sim}{N}\end{array}$ & \\
\hline $\mathrm{SiO}_{2}$ & 24 & 41 & 33 & 16 & 28 & 32 & 27 & 12 & 22 & 31 & 28 & 28 & 27 \\
\hline $\mathrm{Al}_{2} \mathrm{O}_{3}$ & 5 & 9 & 7 & 2 & 5 & 6 & 5 & 3 & 4 & 6 & 5 & 5 & 5 \\
\hline $\mathrm{FeO}$ & 2 & 4 & 3 & 1 & 2 & 3 & 1 & 1 & 2 & 3 & 2 & 2 & 2 \\
\hline $\mathrm{MgO}$ & 3 & 8 & 5 & 2 & 3 & 5 & 3 & 2 & 3 & 5 & 4 & 3 & 4 \\
\hline $\mathrm{CaO}$ & 27 & 13 & 21 & 34 & 27 & 22 & 20 & 28 & 28 & 23 & 18 & 29 & 24 \\
\hline $\mathrm{Na}_{2} \mathrm{O}$ & 1 & 1 & 1 & 0 & 1 & 1 & 1 & 0 & 1 & 0 & 1 & 1 & 1 \\
\hline $\mathrm{K}_{2} \mathrm{O}$ & 1 & 1 & 1 & 1 & 1 & 1 & 1 & 1 & 1 & 2 & 1 & 1 & 1 \\
\hline $\mathrm{CO}_{2}$ & 37 & 23 & 29 & 44 & 33 & 30 & 42 & 53 & 39 & 30 & 41 & 31 & 39 \\
\hline Total & 100 & 100 & 100 & 100 & 100 & 100 & 100 & 100 & 100 & 100 & 100 & 100 & 103 \\
\hline
\end{tabular}




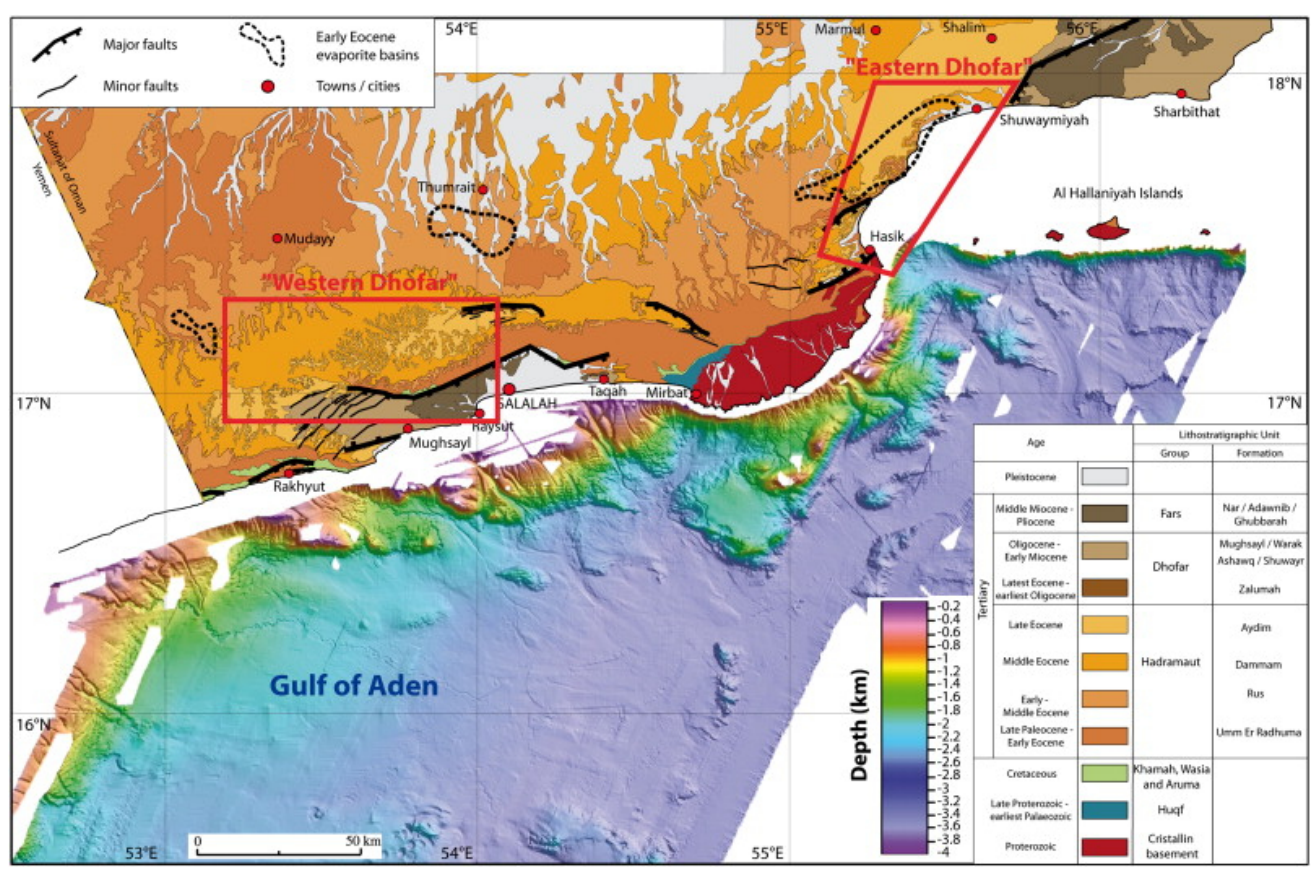

Figure 1

$101 \times 66 \mathrm{~mm}(200 \times 200$ DPI $)$ 


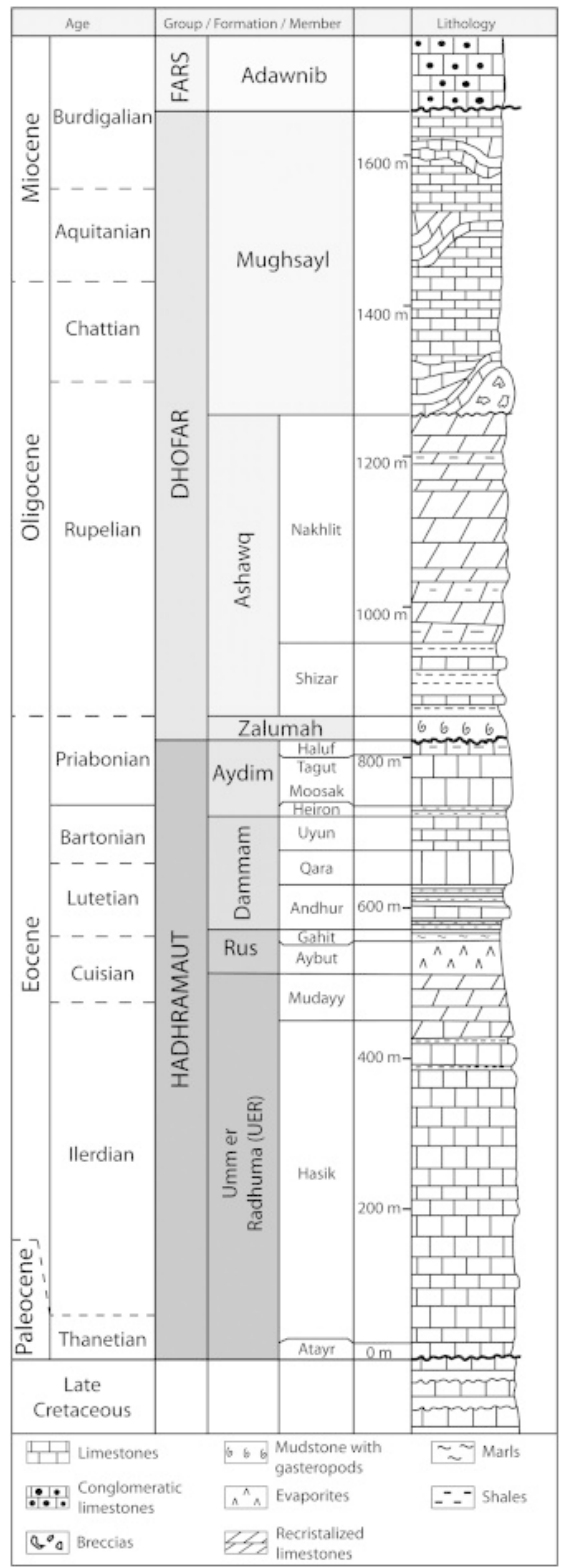

Figure 2

$42 \times 120 \mathrm{~mm}(200 \times 200 \mathrm{DPI})$ 


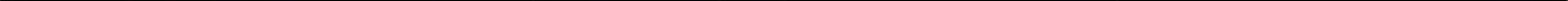



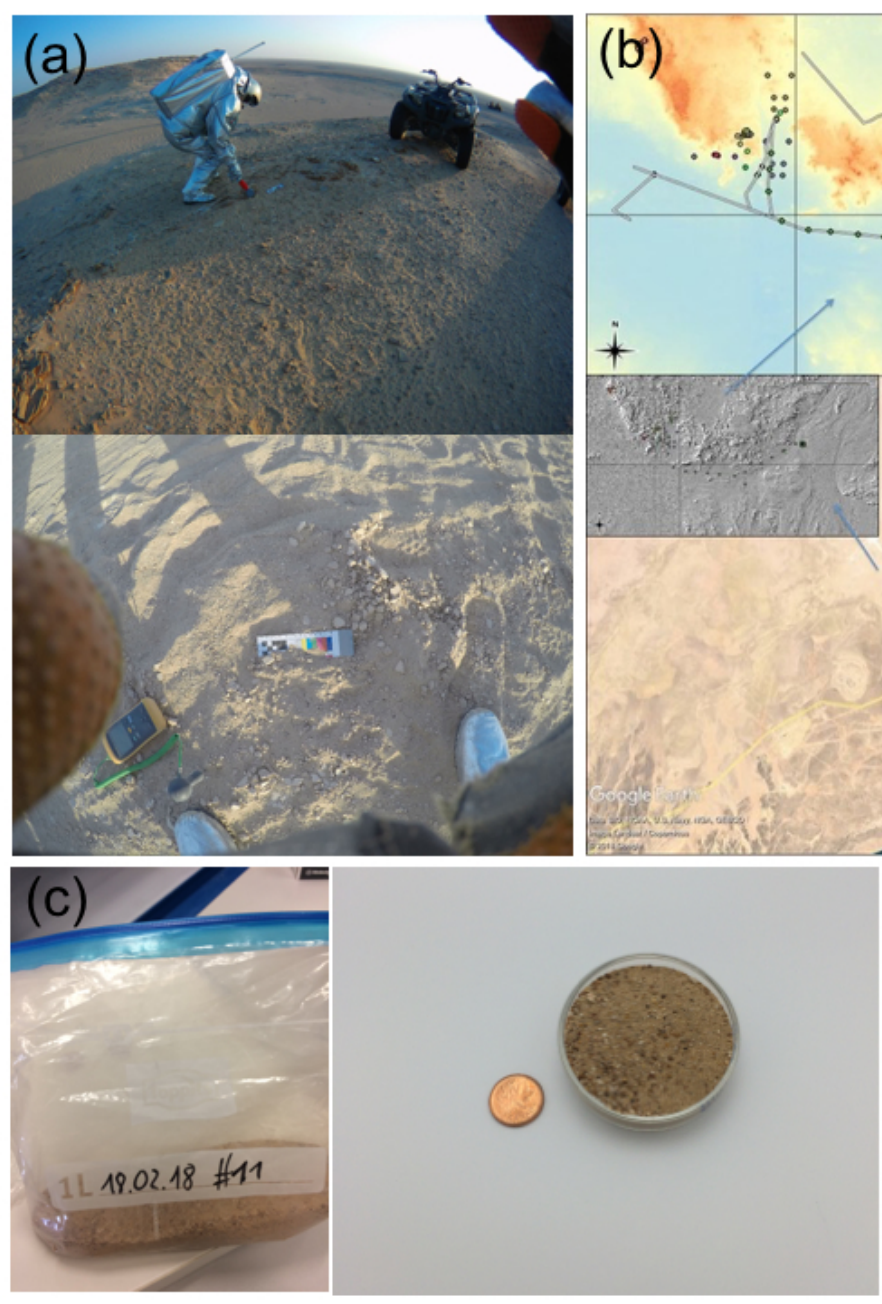

Figure 4

$254 \times 256 \mathrm{~mm}(72 \times 72$ DPI $)$
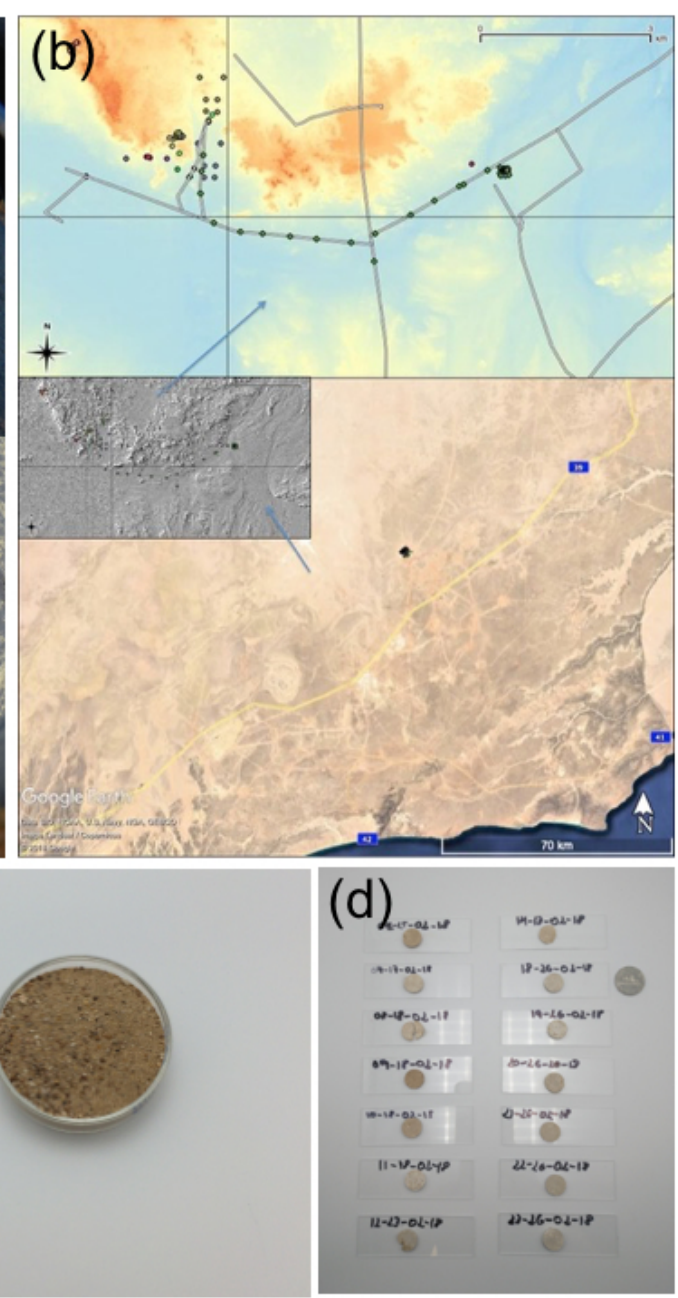

(d)

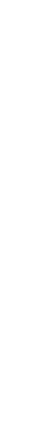



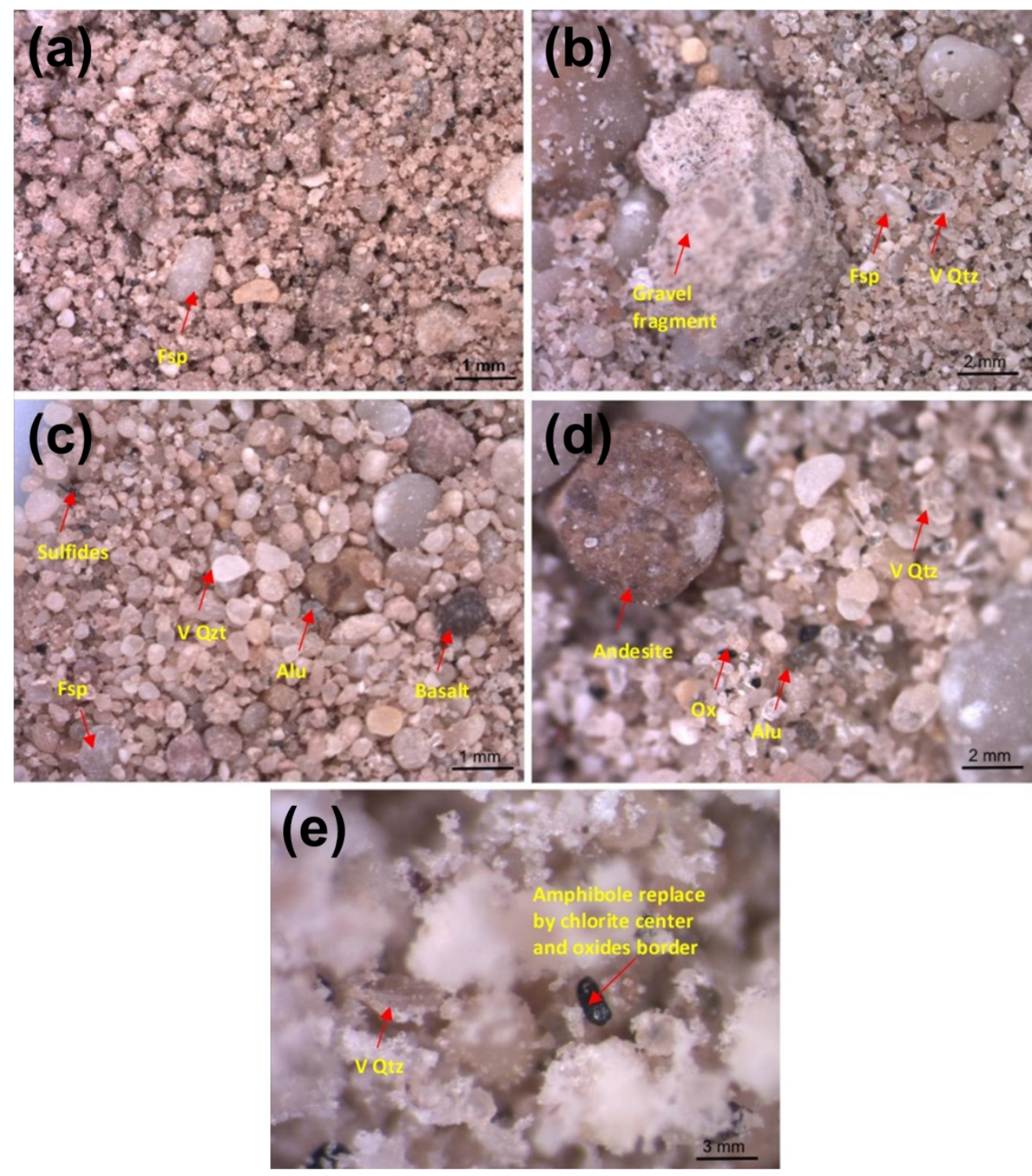

Figure 5 

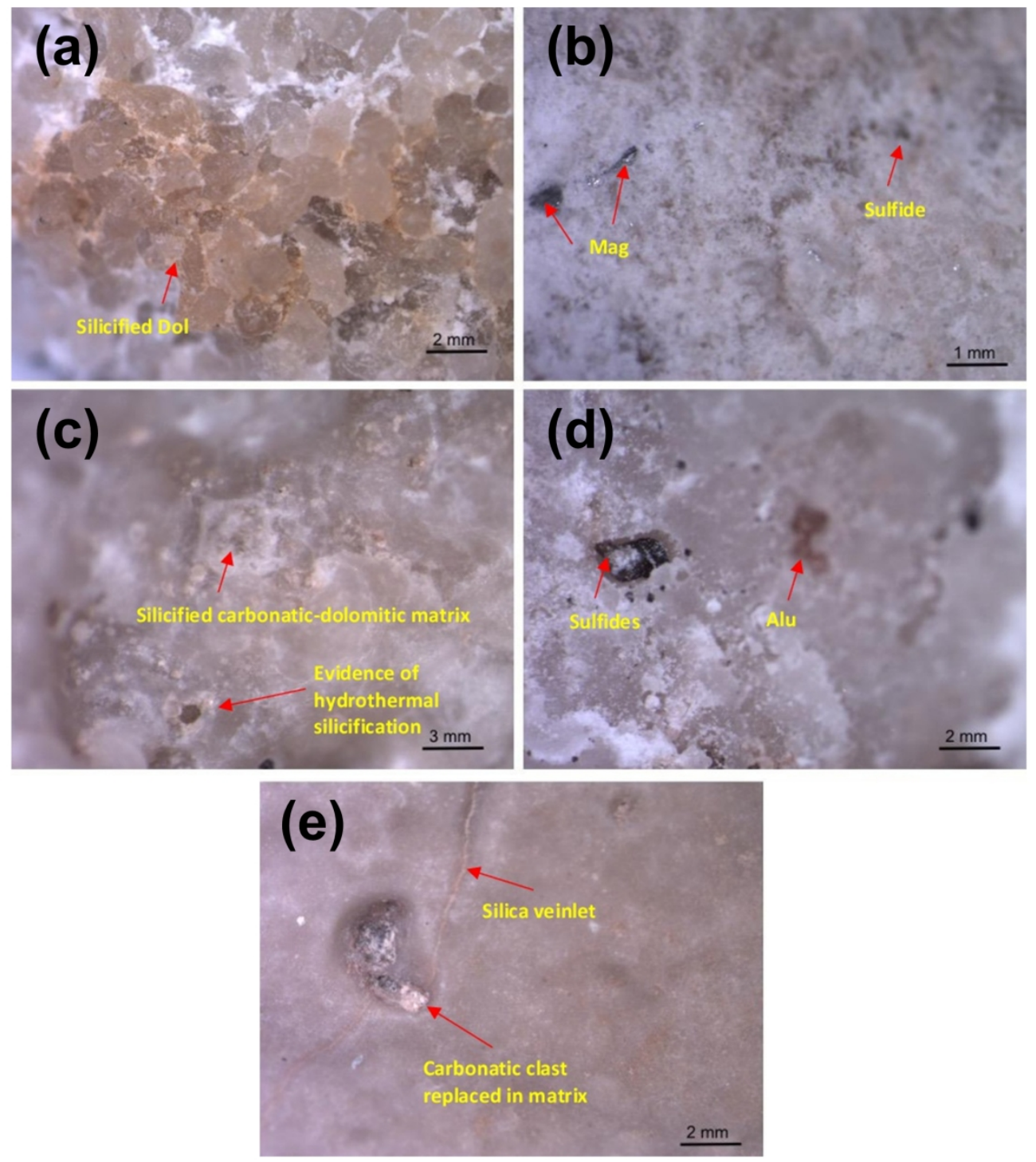

Figure 6 


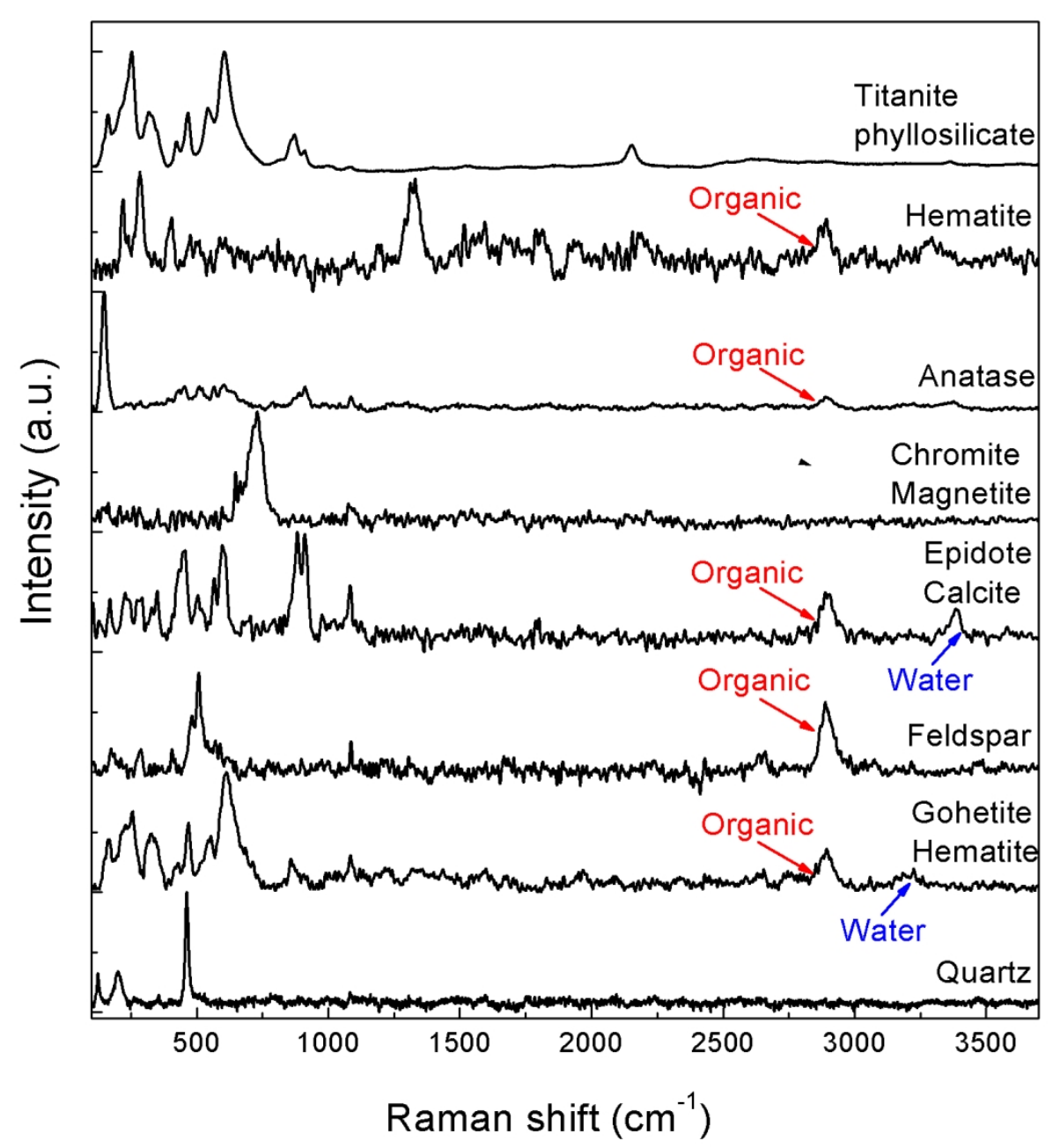

Figure 7 


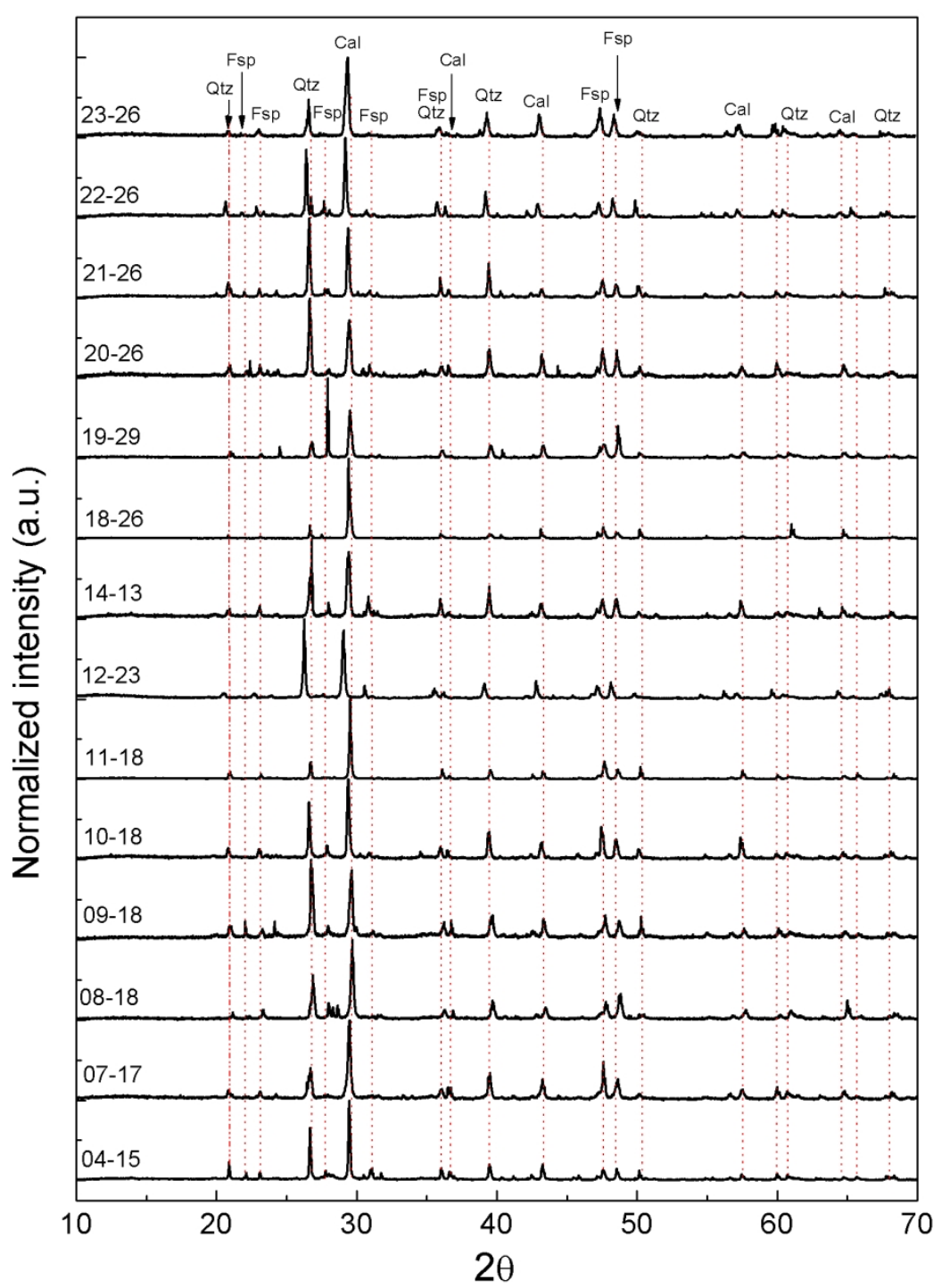

Figure 8 

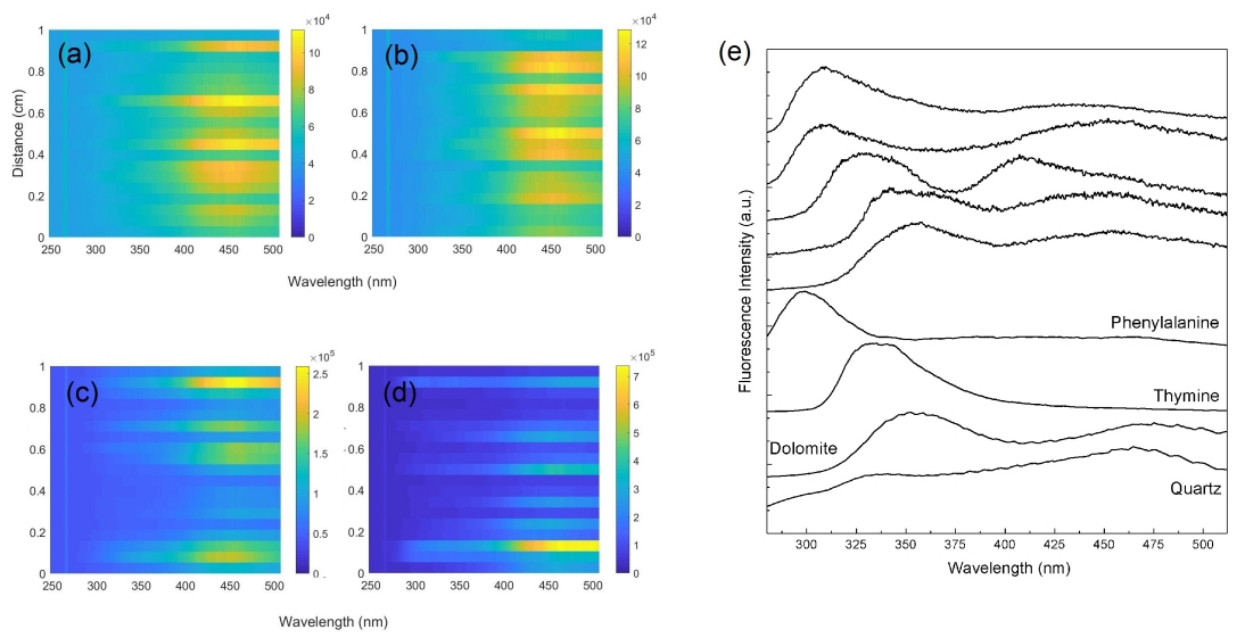

Figure 9 

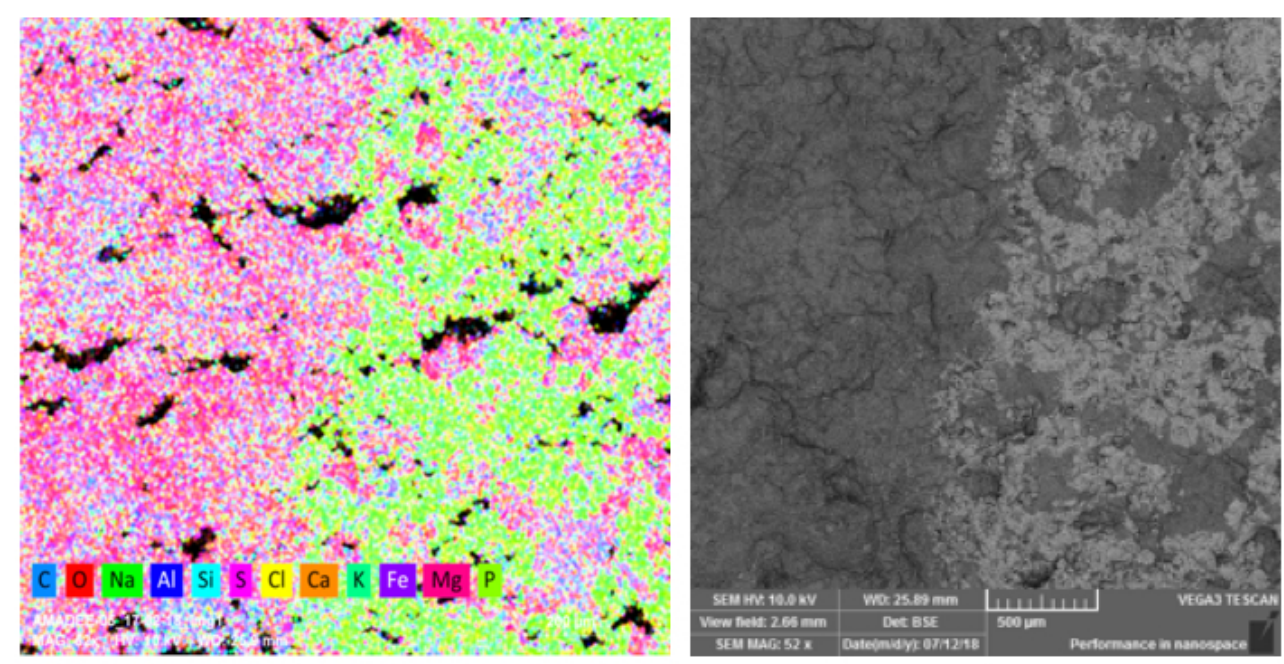

Figure 10 


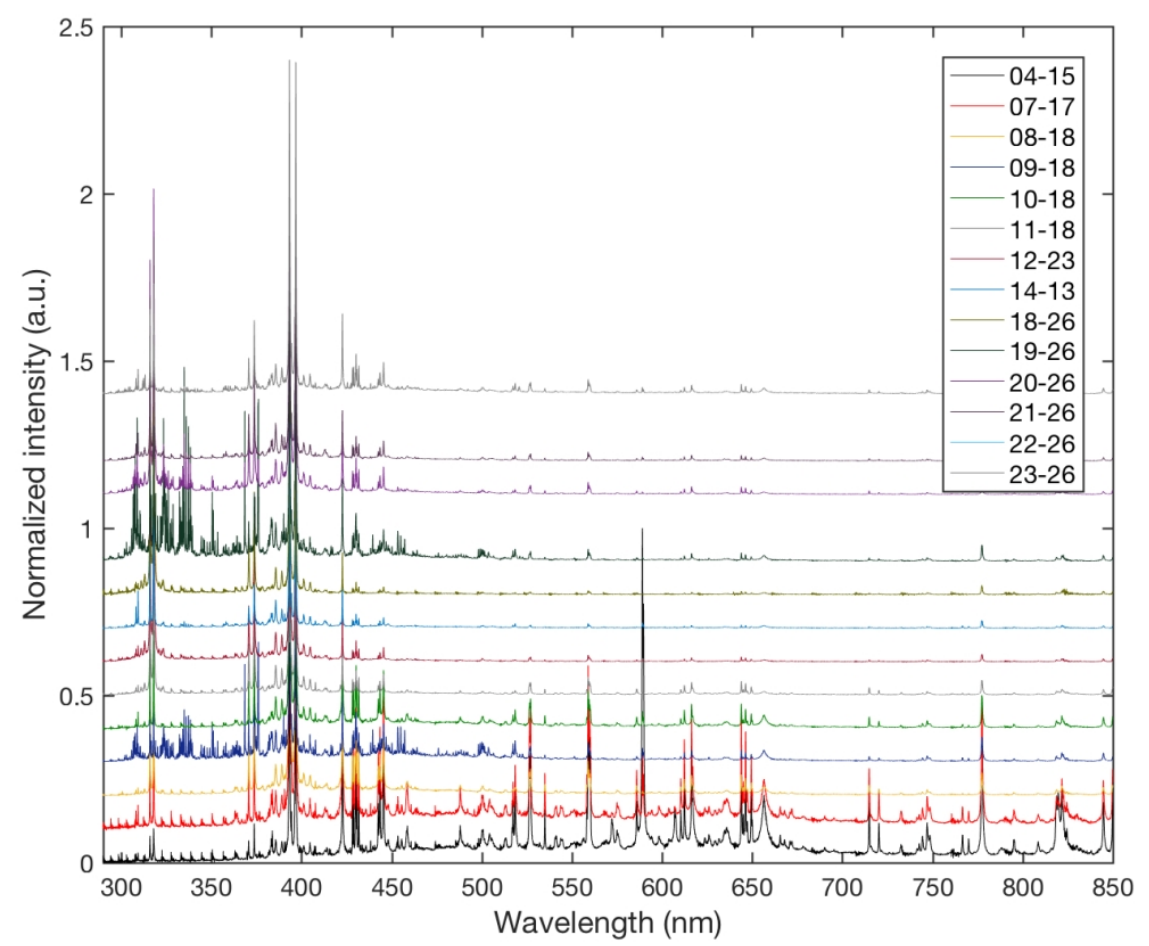

Figure 11

$510 \times 402 \mathrm{~mm}(72 \times 72 \mathrm{DPI})$ 